\title{
Equilibria among titanite, hedenbergite, fayalite, quartz, ilmenite, and magnetite: Experiments and internally consistent thermodynamic data for titanite
}

\author{
Dimitrios Xirouchakis* and Donald H. Lindshey
}

\author{
Center for High Pressure Research and Department of Geosciences, State University of New York at Stony Brook, \\ Stony Brook, New York 11794-2100, U.S.A.
}

\begin{abstract}
For iron-rich compositions, reactions among titanite, clinopyroxene, olivine, quartz, magnetite, and ilmenite can constrain the conditions under which common rocks form. Phase equilibrium experiments in the system $\mathrm{CaO}-\mathrm{FeO}-\mathrm{Fe}_{2} \mathrm{O}_{3}-\mathrm{TiO}_{2}-\mathrm{SiO}_{2}$ constrain two of these reactions:

$$
\begin{aligned}
& \text { clinopyroxene }+ \text { ilmenite }=\text { titanite }+ \text { olivine } \\
& \text { clinopyroxene }+ \text { ilmenite }=\text { titanite }+ \text { magnetite }+ \text { quartz }
\end{aligned}
$$

in the range $600-1100{ }^{\circ} \mathrm{C}$ and $<1$ bar $-3.8 \mathrm{kbar}$, and under controlled $f_{\mathrm{O}_{2}}$ conditions. The experimental results indicate that the assemblage clinopyroxene-ilmenite represents reducing conditions relative to titanite-magnetite-quartz. However, the latter is not necessarily indicative of oxygen fugacity conditions higher than that of the FMQ buffer. The data also strongly suggest that the equilibrium positions of reaction 1 and 2 reflect changes in pressure, temperature, $f_{\mathrm{O}_{2}}, \mathrm{a}_{\mathrm{SiO}_{2}}, \mu \mathrm{Fe}^{2+} \mathrm{Ti}^{4+} \mathrm{Fe}_{-2}^{3+}$, and $\mu \mathrm{CaFe}_{-1}$ in the coexisting $\mathrm{Fe}-\mathrm{Ti}$ oxides and silicates. Standard state thermodynamic data and solution models for $\mathrm{Ca}-\mathrm{Fe}$ olivine and clinopyroxene solid solutions, Fe-Ti ilmenite and magnetite solid solutions, and quartz (QUILF database) allow refinement of standard state thermochemical data for end-member titanite (A2/a space group):

$$
\begin{aligned}
\Delta H^{0} & =-2607.41 \mathrm{~kJ} / \mathrm{mol} \\
S^{0} & =106.00 \mathrm{~J} /(\mathrm{mol} \cdot \mathrm{K}) \\
\Delta G^{0} & =-2458.95 \mathrm{~kJ} / \mathrm{mol}
\end{aligned}
$$

and require modification of published heat capacity equations to:

$$
C_{\mathrm{p}}=\frac{591460608}{T^{3}}-\frac{5118324}{T^{2}}-\frac{1038.4}{\sqrt{T}}+247.47 .
$$

The derived data for titanite are internally consistent with an enthalpy of formation of $-2610.13 \pm 2.90$ ( 2 std. error) $\mathrm{kJ} / \mathrm{mol}$, established by drop solution calorimetry, and are specific to the QUILF database. However, analysis of the experimental results using different internally consistent databases suggest that the revision proposed in this study of the currently accepted entropy value of $129.20 \mathrm{~J} /(\mathrm{mol} \cdot \mathrm{K})$ is largely independent of the databases used. The new entropy is required by the enthalpy of formation for titanite adopted here, which may also require revision of the heat capacity.
\end{abstract}

\section{INTRODUCTION}

Titanite (Sphene), $\mathrm{CaTiSiO}_{5}$, is a common accessory mineral in igneous and metamorphic rocks, and it is probably the most abundant titanium mineral other than ilmenite and rutile. Its principal igneous occurrence is in plutonic rocks (e.g., syenites, diorites, and granites; Deer

\footnotetext{
* Present address: 108 Pillsbury Hall, 310 Pillsbury Drive SE, Department of Geology and Geophysics, University of Minnesota, Twin Cities, Minnesota 55455, U.S.A. E-mail: xirou001@tc.umn.edu
}

et al. 1982), and it is less common in volcanic rocks (Nakada 1991). Titanite is also common in gneisses and schists rich in ferromagnesian minerals (Deer et al. 1982), in calcareous schists (e.g., Gieré 1992), and in high-pressure metamorphic rocks (e.g., Franz and Spear 1985).

Titanite can participate in mineral-mineral, mineralmelt, and mineral-fluid equilibria that can be extremely sensitive to changes in intensive parameters such as pressure, temperature, oxygen fugacity, and fluid composition (e.g., Hunt and Kerrick 1977; Spear 1981; Manning and 


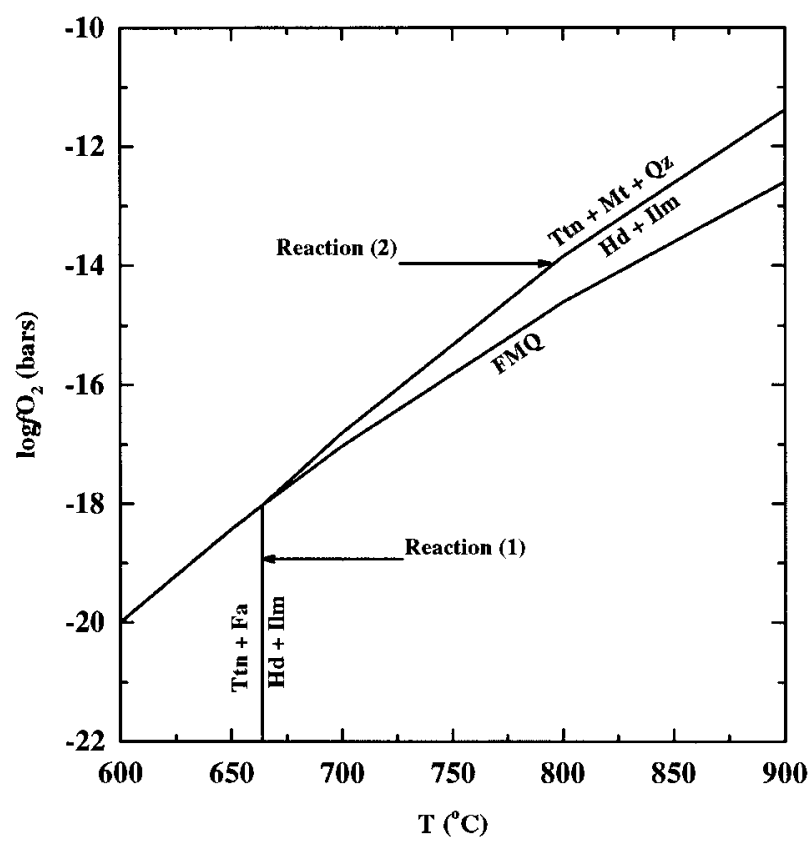

Figure 1. Plot of $f_{\mathrm{O}_{2}}$ vs. T showing the metastable reactions: (1) $\mathrm{Fe}_{2} \mathrm{SiO}_{4}+\mathrm{CaTiSiO}_{5}=\mathrm{FeTiO}_{3}+\mathrm{CaFeSi}_{2} \mathrm{O}_{6}$ and (2) $3 \mathrm{Ca}-$ $\mathrm{FeSi}_{2} \mathrm{O}_{6}+3 \mathrm{FeTiO}_{3}+\mathrm{O}_{2}=\mathrm{CaTiSiO}_{5}+2 \mathrm{Fe}_{3} \mathrm{O}_{4}+\mathrm{SiO}_{2}$ according to Wones (1989) who calculated for pure phases that reactions 1 and 2 should intersect at $664{ }^{\circ} \mathrm{C}$ and $f_{\mathrm{O}_{2}}$ conditions of the FMQ buffer at 1 bar (adapted from Fig. 1 of Wones 1989).

Bohlen 1991). Additionally, because of the ability of titanite to retain certain radionuclides (i.e., uranium, thorium, radium), titanite-based ceramics and glass-ceramics have been proposed as hosts of nuclear waste (e.g., Hayward and Cechetto 1982; Gascoyne 1986).

For iron-rich compositions, reactions among titanite, Fe-Ti oxides, clinopyroxene, olivine, and quartz can constrain the $P-T-f_{\mathrm{O}_{2}}$ conditions under which common titanite-bearing rocks form, such as ilmenite-bearing vs. magnetite-and titanite-bearing granites. Moreover, the presence of titanite places tight constraints on the stability of the more abundant rock-forming minerals.

Wones (1989) discussed the importance of titanitebearing equilibria, particularly the importance of the assemblage titanite-magnetite-quartz. He also calculated the equilibrium $T$ and $f_{\mathrm{O}_{2}}$ conditions of the following titanitebearing reactions for pure phases in the system $\mathrm{CaO}-\mathrm{FeO}-$ $\mathrm{Fe}_{2} \mathrm{O}_{3}-\mathrm{TiO}_{2}-\mathrm{SiO}_{2}$ at 1 bar:

$$
\begin{aligned}
& \mathrm{CaFeSi}_{2} \mathrm{O}_{6}+\mathrm{FeTiO}_{3}=\mathrm{Fe}_{2} \mathrm{SiO}_{4}+\mathrm{CaTiSiO}_{5} \\
& \text { hedenbergite ilmenite fayalite titanite } \\
& \mathrm{CaFeSi}_{2} \mathrm{O}_{6}+\mathrm{FeTiO}_{3}+1 / 3 \mathrm{O}_{2}=\mathrm{CaTiSiO}_{5}+2 / 3 \mathrm{Fe}_{3} \mathrm{O}_{4} \\
& \text { hedenbergite ilmenite titanite magnetite } \\
& +\mathrm{SiO}_{2} \text {. } \\
& \text { quartz }
\end{aligned}
$$

He proposed that reaction 1 and 2 should generate an invariant point at their intersection with the FMQ buffer curve (Fig. 1). Wones' location of reaction 2 above the
TABLE 1. Equilibria among clinopyroxene, olivine, ilmenite, magnetite, titanite, quartz, and iron in the system $\mathrm{CaO}-\mathrm{FeO}-\mathrm{Fe}_{2} \mathrm{O}_{3}-\mathrm{TiO}_{2}-\mathrm{SiO}_{2}$ pertaining to Figure 2

1. Titanite + olivine + clinopyroxene $+\mathrm{Fe}$-Ti oxides + quartz + iron $2 \mathrm{CaTiSiO}_{5}+30 \mathrm{Fe}_{2} \mathrm{SiO}_{4}=2 \mathrm{CaFeSi}_{2} \mathrm{O}_{6}+2 \mathrm{Fe}_{2} \mathrm{TiO}_{4}+\mathrm{SiO}_{2}$ $\mathrm{CaTiSiO}_{5}+\mathrm{oFe}_{2} \mathrm{SiO}_{4}=\mathrm{aCaFeSi}_{2} \mathrm{O}_{6}+\mathrm{FeTiO}_{3}$

$3 \mathrm{CaTiSiO}_{5}+2 \mathrm{Fe}_{3} \mathrm{O}_{4}=30 \mathrm{CaFeSiO}{ }_{4}+3 \mathrm{FeTiO}_{3}+\mathrm{O}_{2}$

$4 \mathrm{CaTiSiO}+6 \mathrm{Fe}_{2} \mathrm{O}_{3}=40 \mathrm{CaFeSiO}{ }_{4}+4 \mathrm{Fe}_{2} \mathrm{TiO}_{4}+3 \mathrm{O}_{2}$

$3 \mathrm{CaTiSiO}_{5}+2 \mathrm{Fe}_{3} \mathrm{O}_{4}+3 \mathrm{SiO}_{2}=3 \mathrm{aCaFeSi}_{2} \mathrm{O}_{6}+3 \mathrm{FeTiO}_{3}+\mathrm{O}_{2}$

$2 \mathrm{CaTiSiO}_{5}+4 \mathrm{Fe}_{2} \mathrm{TiO}_{4}+2 \mathrm{SiO}_{2}=2 \mathrm{aCaFeSi}_{2} \mathrm{O}_{6}+6 \mathrm{FeTiO}_{3}$

$\mathrm{CaTiSiO}+2 \mathrm{Fe}+\mathrm{O}_{2}=0 \mathrm{oCaFeSiO}_{4}+\mathrm{FeTiO}_{3}$

$2 \mathrm{CaTiSiO}_{5}+6 \mathrm{Fe}+3 \mathrm{O}_{2}=20 \mathrm{CaFeSiO}{ }_{4}+2 \mathrm{Fe}_{2} \mathrm{TiO}_{4}$

$\mathrm{CaTiSiO}+2 \mathrm{Fe}+\mathrm{SiO}_{2}+\mathrm{O}_{2}=\mathrm{aCaFeSi}_{2} \mathrm{O}_{6}+\mathrm{FeTiO}_{3}$

$2 \mathrm{CaTiSiO}{ }_{5}+6 \mathrm{Fe}+2 \mathrm{SiO}_{2}+3 \mathrm{O}_{2}=2 \mathrm{aCaFeSi} \mathrm{O}_{6}+2 \mathrm{Fe}_{2} \mathrm{TiO}_{4}$

2. Olivine + clinopyroxene $+\mathrm{Fe}-\mathrm{Ti}$ oxides + quartz + iron

$\mathrm{aCaFeSi} \mathrm{O}_{6}+\mathrm{oFe}_{2} \mathrm{SiO}_{4}=0 \mathrm{oCaFeSi}_{2} \mathrm{O}_{4}+\mathrm{aFe}_{2} \mathrm{Si}_{2} \mathrm{O}_{6}$

$\mathrm{aFe}_{2} \mathrm{Si}_{2} \mathrm{O}_{6}=\mathrm{OFe}_{2} \mathrm{SiO}_{4}+\mathrm{SiO}_{2}$

$\mathrm{aCaFeSi} \mathrm{O}_{6}=0 \mathrm{oCaFeSi}_{2} \mathrm{O}_{4}+\mathrm{SiO}_{2}$

$2 \mathrm{oFe}_{2} \mathrm{SiO}_{4}+\mathrm{O}_{2}=2 \mathrm{Fe}_{2} \mathrm{O}_{3}+2 \mathrm{SiO}_{2}$

$30 \mathrm{Fe}_{2} \mathrm{SiO}_{4}+\mathrm{O}_{2}=2 \mathrm{Fe}_{3} \mathrm{O}_{4}+3 \mathrm{SiO}_{2}$

$2 \mathrm{aFe}_{2} \mathrm{Si}_{2} \mathrm{O}_{6}+\mathrm{O}_{2}=2 \mathrm{Fe}_{2} \mathrm{O}_{3}+4 \mathrm{SiO}_{2}$

$\mathrm{aFe} \mathrm{Si}_{2} \mathrm{O}_{6}+\mathrm{O}_{2}=\mathrm{Fe}_{3} \mathrm{O}_{4}+2 \mathrm{SiO}_{2}$

$2 \mathrm{Fe}+\mathrm{SiO}_{2}+\mathrm{O}_{2}=\mathrm{oFe}_{2} \mathrm{SiO}_{4}$

$2 \mathrm{Fe}+2 \mathrm{SiO}_{2}+\mathrm{O}_{2}=\mathrm{aFe}_{2} \mathrm{Si}_{2} \mathrm{O}$

3. Fe-Ti oxides + iron

$\mathrm{Fe}_{2} \mathrm{TiO}_{4}+\mathrm{Fe}_{2} \mathrm{O}_{3}=\mathrm{FeTiO}_{3}+\mathrm{Fe}_{3} \mathrm{O}_{4}$ $4 \mathrm{Fe}_{3} \mathrm{O}_{4}+\mathrm{O}_{2}=6 \mathrm{Fe}_{2} \mathrm{O}_{3}$

$2 \mathrm{FeTiO}_{3}+2 \mathrm{Fe}+\mathrm{O}_{2}=2 \mathrm{Fe}_{2} \mathrm{TiO}_{4}$

Note: Titanite and quartz are considered pure phases whereas olivine (o) is treated as solid solution of $\mathrm{Fe}_{2} \mathrm{SiO}_{4}-\mathrm{CaFeSiO}_{4}$, clinopyroxene (a) of $\mathrm{CaFeSi} \mathrm{O}_{6}-\mathrm{Fe}_{2} \mathrm{Si}_{2} \mathrm{O}_{6}$, ilmenite of $\mathrm{Fe}_{2} \mathrm{O}_{3}-\mathrm{FeTiO}_{3}$, and magnetite of $\mathrm{Fe}_{3} \mathrm{O}_{4}-$ $\mathrm{Fe}_{2} \mathrm{TiO}_{4}$ components.

FMQ buffer curve is correct for metastable equilibrium among the pure phases. Consequently, the invariant point generated by their intersection is also metastable. If we assume for the moment that titanite (Ttn) and quartz $(\mathrm{Qz})$ are pure phases, and we treat hedenbergite $\left(\mathrm{Hd}_{\mathrm{ss}}\right)$, fayalite $\left(\mathrm{Fa}_{\mathrm{ss}}\right)$, ilmenite $\left(\mathrm{Il}_{\mathrm{ss}}\right)$, and magnetite $\left(\mathrm{Mt}_{\mathrm{ss}}\right)$, respectively, as $\mathrm{CaFeSi}{ }_{2} \mathrm{O}_{6}-\mathrm{Fe}_{2} \mathrm{Si}_{2} \mathrm{O}_{6}$ (Hd-Cfs), $\mathrm{Fe}_{2} \mathrm{SiO}_{4}-\mathrm{CaFeSiO}_{4}$ ( $\mathrm{Fa}-$ $\mathrm{Ks}$ ), $\mathrm{FeTiO}_{3}-\mathrm{Fe}_{2} \mathrm{O}_{3}$ (Il-Hem), and $\mathrm{Fe}_{3} \mathrm{O}_{4}-\mathrm{Fe}_{2} \mathrm{TiO}_{4}$ (Mt-Usp) solid solutions, the variables are: $P, T, f_{\mathrm{O}_{2}}, a_{\mathrm{SiO}_{2}}$, $\mu \mathrm{Fe}^{2+} \mathrm{Ti}^{4+} \mathrm{Fe}_{-2}^{3+}$, and $\mu \mathrm{CaFe}_{-1}$ (Lindsley and Frost 1992). Hence, chemical equilibrium among physically real phases could be modeled by writing the stoichiometric reactions among phase components (Table 1). Moreover, the reactions among $\mathrm{Ttn}, \mathrm{Hd}_{\mathrm{ss}}, \mathrm{Fa}_{\mathrm{ss}}, \mathrm{Il}_{\mathrm{ss}}, \mathrm{Mt}_{\mathrm{ss}}$, and $\mathrm{Qz}$ should generate a stable invariant point I that lies below the FMQ buffer (Fig. 2). Note that at constant pressure and low $f_{\mathrm{O}_{2}}$, the divariant assemblage $\mathrm{Hd}_{\mathrm{ss}}+\mathrm{Il}_{\mathrm{ss}}+\mathrm{Fa}_{\mathrm{ss}}+\mathrm{Ttn}$ (reaction 1) is terminated at invariant point II by its intersection with the reaction

$$
\text { fayalite }_{\mathrm{ss}}=\text { hedenbergite }_{\mathrm{ss}}+\text { iron }+ \text { quartz }
$$

where fayalite is $_{\mathrm{s}} \mathrm{Ca}$-saturated with respect to hedenbergite $_{\text {ss }}$ (Fig. 2). At low oxygen fugacity conditions, the intersection of reaction 3 with

$$
\underset{\text { ülvospinel }}{2 \mathrm{Fe}_{2} \mathrm{TiO}_{4}}=\underset{\text { iron }}{2 \mathrm{Fe}}+\underset{\text { ilmenite }}{2 \mathrm{FeTiO}_{3}}+\mathrm{O}_{2}
$$

generates a third invariant point (III), which is the termination of the Ttn-absent (Ca-QUILF) reaction 


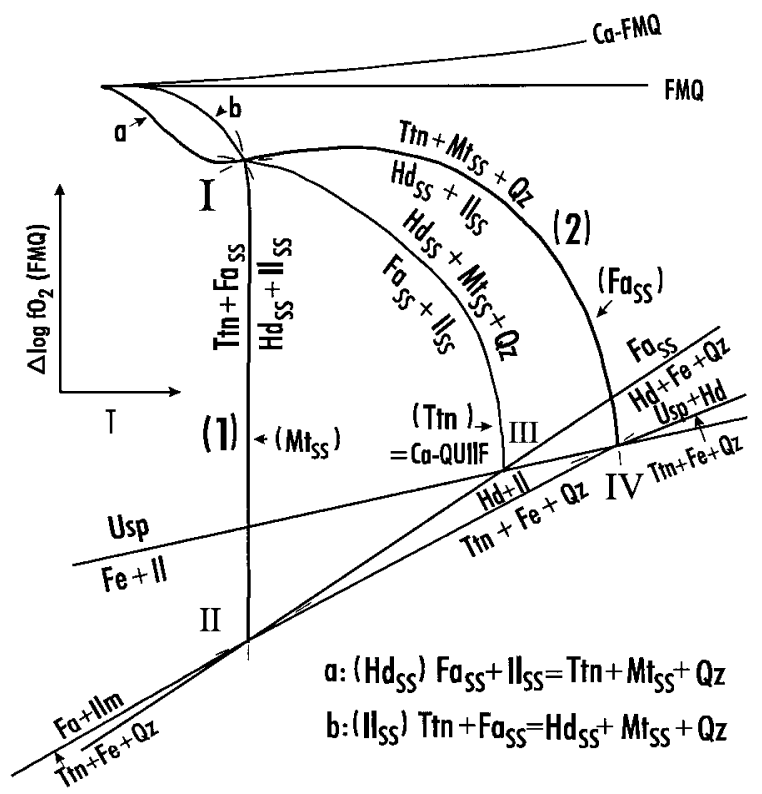

Figure 2. Schreinemakers analysis of low pressure equilibria among titanite, hedenbergite ${ }_{\mathrm{ss}}$, fayalite ss $_{\mathrm{s}}$, quartz, ilmenite ss $_{\text {, }}$ magnetite ${ }_{\mathrm{ss}}$, and $\mathrm{Fe}^{0}$.

$$
\begin{aligned}
\text { fayalite }_{\mathrm{ss}}+\text { ilmenite }_{\mathrm{ss}}= & \text { hedenbergite }_{\mathrm{ss}}+\text { magnetite }_{\mathrm{ss}} \\
& + \text { quartz }
\end{aligned}
$$

(Fig. 2). In addition, at constant pressure, relatively low $f_{\mathrm{O}_{2}}$, and high-temperature conditions the intersection of reaction 4 with reaction 2 generates a fourth invariant point (IV). Thus, for real phases, the path of reaction 2 is very different from that deduced by Wones for pure phases. At point IV, magnetite ${ }_{\mathrm{ss}}$, $^{\text {ilmenite }}$ ss $_{\mathrm{s}}$, and hedenbergite ${ }_{\mathrm{ss}}$ would have to approach the $\mathrm{Fe}_{2} \mathrm{TiO}_{4}, \mathrm{FeTiO}_{3}$, and $\mathrm{CaFeSi}_{2} \mathrm{O}_{6}$ end-member compositions, respectively. At higher oxygen fugacity and lower temperature conditions, the Ca-FMQ reaction

$$
\text { fayalite }_{\mathrm{ss}}=\text { magnetite }+ \text { quartz }+ \text { minor hedenbergite }_{\mathrm{ss}}
$$

and the $\mathrm{Hd}_{\mathrm{ss}}-$ and $\mathrm{Il}_{\mathrm{ss}}$-absent reactions of Figure 2 must all merge asymptotically with the FMQ buffer curve as the fayalite loses $\mathrm{Ca}$ and the magnetite loses $\mathrm{Ti}$ with decreasing temperature.

In this paper, we concentrate on the geologically more important reactions 1 and 2 . To date there have been no experimental constraints for these two reactions. The location of reactions 1 and 2, and therefore of the stable invariant point I, are poorly known. The calculations of Wones place reaction 1 on the FMQ buffer curve at 664 ${ }^{\circ} \mathrm{C}$ at 1 bar, and thus the location of the metastable invariant point on the FMQ buffer curve at that temperature (Fig. 1), values that are consistent with results of our experiments. In contrast, calculations using thermodynamic data for pure phases from Berman (1991) and Holland and Powell (1990) place reaction 1 at $1000{ }^{\circ} \mathrm{C}$ and at $-62{ }^{\circ} \mathrm{C}$, respectively. A partial explanation for this dis- crepancy may lie in the fact that the available thermochemical data for titanite (King et al. 1954; Todd and Kelley 1956) are suspect (Xirouchakis et al. 1997a, 1997b). Thus experimental location of reactions 1 and 2 can provide important new constraints on those thermochemical data. We conducted reversed experiments under controlled oxygen fugacity conditions to locate reactions 1 and 2 at pressures ranging from $<1$ atm to $3.8 \mathrm{kbar}$. Subsequently, we used the phase equilibrium experiments to derive thermodynamic data for titanite, which is internally consistent with the thermodynamic database and solution models in Andersen et al. (1993) and with the new calorimetric measurements of the enthalpy of formation in Xirouchakis et al. (1997b).

\section{EXPERIMENTAL DETAILS}

Starting materials for the phase-equilibrium experiments were synthesized by reacting appropriate mixtures of high-purity chemicals [FeO: weighed as Fe "sponge" (JMC S50389B) and $\mathrm{Fe}_{2} \mathrm{O}_{3}$ (JM S5040B), $\mathrm{SiO}_{2}$ (JM S50389B), $\mathrm{TiO}_{2}$ (JMC 810420), and $\mathrm{CaCO}_{3}$ (ALPHA Lot 050980)]. Details of the syntheses and microprobe data for starting materials are given in Xirouchakis (1997) and specifically for titanite in Xirouchakis et al. (1997a, 1997b). The phases used in the experiments were extremely pure, as indicated by powder X-ray diffraction (XRD), electron microprobe analysis, and optical examination. Reactions 1 and 2 were constrained by reacting mechanical mixtures of crystalline phases ( $\mathrm{Hd}-\mathrm{Il}$ or $\mathrm{Hd}_{\mathrm{ss}}-$ $\mathrm{Il}_{\mathrm{ss}}$ and $\mathrm{Ttn}-\mathrm{Fa}$, and $\mathrm{Hd}-\mathrm{Il}$ or $\mathrm{Hd}_{\mathrm{ss}}-\mathrm{Il}_{\mathrm{ss}}$ and $\mathrm{Ttn}-\mathrm{Mt}_{\mathrm{ss}}-\mathrm{Qz}$ or Ttn-2/3Mt-Qz) using the double capsule technique under anhydrous (in vacuo) and hydrothermal conditions.

The $<1$ atm experiments were performed in fastquench (vertical) platinum-wound furnaces. The temperature was monitored with $\mathrm{Pt}-\mathrm{Pt}_{90} \mathrm{Rh}_{10}$ thermocouples calibrated against the melting point of $\mathrm{Au}$ at room pressure. The starting mechanical mixtures were loaded into either iron capsules with tightly fitted lids or (for experiments at oxygen fugacity conditions of the WM, Co- $\mathrm{SiO}_{2}-$ $\mathrm{Co}_{2} \mathrm{SiO}_{4}$, and $\mathrm{Co}-\mathrm{CoO}$ buffers) into $\mathrm{Ag}_{80} \mathrm{Pd}_{20}$ capsules ( $T$ $\left.\leq 1050{ }^{\circ} \mathrm{C}\right)$ or $\mathrm{Ag}_{70} \mathrm{Pd}_{30}$ capsules $\left(T \geq 1050{ }^{\circ} \mathrm{C}\right)$ crimped at the top and sealed in silica-glass tubes. (While not strictly buffered, the actual oxygen fugacity conditions for the Fe-saturated experiments in silica-glass tubes are effectively limited between the reactions: iron + silica $=$ fayalite and iron + ilmenite $=$ spinel; lower and upper limit, respectively.) The buffer mixtures were also loaded in crimped $\mathrm{Ag}_{80} \mathrm{Pd}_{20}$ or $\mathrm{Ag}_{70} \mathrm{Pd}_{30}$ capsules and placed between the capsules that contained the starting mechanical mixtures. The experiments were terminated by dropping the silica-glass tubes into a glass beaker filled with water or by cooling them in a stream of compressed air. No changes were observed in the Fe capsules that could indicate oxidation during the experiments. Partial alloying of $\mathrm{Co}$ from the $\mathrm{Co}-\mathrm{CoO}$ buffer with the inner walls of $\mathrm{Ag}_{80} \mathrm{Pd}_{20}$ capsules was observed. However, because the largest part of the $\mathrm{Co}-\mathrm{CoO}$ mixture was recovered, it is believed that the integrity of the buffer was not affected. 
The 1 to 3.8 kbar experiments were performed in standard cold-seal pressure vessels (e.g., Kerrick 1987) with $\mathrm{H}_{2} \mathrm{O}$ as the pressure medium placed in horizontal resistance heaters. The temperature was measured by type $\mathrm{K}$ thermocouples. The hot spot in each pressure vessel was calibrated using a sheathed thermocouple calibrated against a NIST standard thermocouple. Pressure was measured by a Bourdon-tube gauge. Approximately 60 to $80 \mathrm{mg}$ of the starting mixtures were loaded with $10 \mu \mathrm{l}$ $\mathrm{H}_{2} \mathrm{O}$ in $\mathrm{Ag}_{80} \mathrm{Pd}_{20}$ capsules, welded shut, and enclosed together with the appropriate solid oxygen buffer (i.e., WM, Co-CoO, FMQ) plus $50 \mu \mathrm{l} \mathrm{H}_{2} \mathrm{O}$ in thick-walled, $38 \mathrm{~mm}$ long gold capsules. The experiments were terminated by taking the vessels out of the heaters and isobarically cooling them by flowing a stream of compressed air over them. Subsequently, the pressure vessels were left to cool for approximately 20 to $45 \mathrm{~min}$ under pressure and then the pressure was released. The gold and $\mathrm{Ag}_{80} \mathrm{Pd}_{20}$ capsules were retrieved, cleaned, and weighed to ensure that no significant weight change or vapor loss had occurred. The capsules were punctured, weighed, placed in a glass vial and heated at $110{ }^{\circ} \mathrm{C}$, and weighed again. Vapor condensation on the walls of the vial and/or significant weight change after heating strongly suggest the presence of a vapor phase throughout the duration of the experiment. No alloying was detected optically or by occasional EDS analyses between the $\mathrm{Co}-\mathrm{CoO}$ mixture and the $\mathrm{Ag}_{80} \mathrm{Pd}_{20}$ capsules in the hydrothermal experiments. Temperature uncertainties include thermocouple and hot-spot calibration uncertainties plus the standard deviation as calculated from the daily readings. Pressure uncertainties reflect the range of values as recorded daily.

The experimental products were examined in oil mounts under a petrographic microscope and by powder XRD using $\mathrm{Cu} K \alpha$ radiation. The buffer mixtures after each experiment were examined to ensure that all phases remained present i.e., (solids + vapor). In addition, some of the experimental products were examined optically by backscattered electron imaging and EDS analysis. Samples were also selected for quantitative analysis (WDS) using a CAMEBAX, four-spectrometer, electron microprobe. Analytical conditions were $15 \mathrm{kV}$, a $20 \mathrm{nA}$ beam current, $1 \mu \mathrm{m}$ beam, and counting times of 50 or $60 \mathrm{~s}$ with required precision of $0.3 \%$. The standards were anorthite (USMN 137041) and titanite (C.M. Taylor Corporation) for $\mathrm{Ca}(\mathrm{Ca} K \alpha), \mathrm{Si}(\mathrm{Si} K \alpha)$, and $\mathrm{O}(\mathrm{O} K \alpha)$, ilmenite (USMN 96189) for $\mathrm{Ti}(\mathrm{Ti} K \alpha)$, and fayalite (USMN 85276) for $\mathrm{Fe}(\mathrm{Fe} K \alpha)$. Oxygen analyses were performed with a multilayered WSi crystal. Raw data were reduced mainly with the PAP and with the ZAF procedure in some cases. The analyses were accepted if the sum of the elements was $100 \pm 2$ wt\% (Xirouchakis 1997; see Tables $2,{ }^{1} 3,{ }^{1}$ and $4^{1}$ ).

${ }^{1}$ For a copy of Tables 2, 3, and 4, Document item AM-98011, contact the Business Office of the Mineralogical Society of America (see inside front cover of recent issue) for price information. Deposit items may also be available on the American Mineralogist web site at http://www.minsocam.org.
It was not always feasible to collect mineral composition data because of the fine grain size and the textural relations, particularly for titanite that grew at the expense of hedenbergite and ilmenite. Fe-Ti oxide compositions were also determined from calibration curves with a precision of $1-2 \%$ (Lindsley, unpublished data) based on the XRD pattern of synthetic single phase $\mathrm{Il}_{\mathrm{ss}}$ [i.e., (214), (116), and (204) peaks] and $\mathrm{Mt}_{\mathrm{ss}}$ [i.e., (622), (533), (620), and (440) peaks]. Most of the reported compositions for hedenbergite ${ }_{\mathrm{ss}}$ were determined with the microprobe. If the XRD pattern permitted, the (220), (31 $\overline{1})$, and (150) reflections were also utilized to derive the $\mathrm{Ca}$ content from the calibration curves of Turnock et al. (1973).

Grain overlap and fluorescence are likely responsible for the apparent $\mathrm{Ti}$ detected in fayalite and hedenbergite, $\mathrm{Ca}$ and $\mathrm{Si}$ in the iron-titanium oxides, and $\mathrm{Fe}$ in titanite. This conclusion is based on: (1) the observed textural relations in the experimental products; (2) the highly variable concentration of these elements within the same grain and from grain to grain; (3) that the concentration of these elements is similar in product phases and in synthetic phases from mechanical mixtures that showed no change after reaction and in starting mechanical mixtures; and (4) the fact that the apparent percentages of $\mathrm{Ca}$ and $\mathrm{Si}$ in the oxides, $\mathrm{Ti}$ in hedenbergite, and $\mathrm{Fe}$ in titanite correlate better with the weight content of each of these elements in the starting mechanical mixtures than with temperature and pressure or oxygen fugacity conditions (Xirouchakis 1997).

As a result, clinopyroxene and iron-titanium oxides are treated as $\mathrm{CaFeSi}_{2} \mathrm{O}_{6}-\mathrm{Fe}_{2} \mathrm{Si}_{2} \mathrm{O}_{6}, \mathrm{FeTiO}_{3}-\mathrm{Fe}_{2} \mathrm{O}_{3}$, and $\mathrm{Fe}_{3} \mathrm{O}_{4}$ $\mathrm{Fe}_{2} \mathrm{TiO}_{4}$ solid solutions, respectively. Minor adjustments were made to correct for the apparent $\mathrm{Ca}$ and $\mathrm{Si}$ in the oxides, and $\mathrm{Ti}$ in clinopyroxene based on the degree and sign of correlation among the elements from the analyses of the products and minerals of known composition in unreacted mechanical mixtures (Xirouchakis 1997). Based on the available data, titanite and fayalite are considered to retain end-member composition (i.e., $\mathrm{CaTiSiO}_{5}$ and $\mathrm{Fe}_{2} \mathrm{SiO}_{4}$, respectively). The assumption that fayalite retains end-member composition is not critical because the Ca content of fayalite in the temperature range 600$800{ }^{\circ} \mathrm{C}$ would have been generally small, $\leq 1 \mathrm{~mol} \%$ (Davidson and Lindsley 1994). All but one of the titanite analyses come from reacted $\mathrm{Ttn}+2 / 3 \mathrm{Mt}+\mathrm{Qz}$ mixtures that always produced the Ilmenite-absent assemblage $\mathrm{Ttn}+\mathrm{Mt}_{\mathrm{ss}}+\mathrm{Qz}+\mathrm{Hd}_{\mathrm{ss}}$. Thus, for titanite there are not as many chemical data to support firmly this assumption of end-member composition. However, indirect evidence comes from the observation that mixtures of end-member titanite, magnetite, and quartz equilibrated at $T, P$, and $f_{\mathrm{O}_{2}}$ conditions where titanite is stable, produced a final mixture of iron-free $\mathrm{Ttn}, \mathrm{Mt}_{\mathrm{ss}}, \mathrm{Qz}$, and $\mathrm{Hd}_{\mathrm{ss}}$.

\section{EXPERIMENTAL RESULTS}

\section{Reaction 1}

The results for reaction 1 are listed in Table 5 and all but one data point at $3.4 \mathrm{kbar}$ and $750{ }^{\circ} \mathrm{C}$ (CCO buffer) 
TABLE 5. Reaction1: Fe-saturated experiments (i.e., Fe capsule container)

\begin{tabular}{|c|c|c|c|c|c|}
\hline$P$ (bar) & $T\left({ }^{\circ} \mathrm{C}\right)$ & Duration (h) & Reactants & Products & Experiment no. \\
\hline$<1$ & $1000(3)$ & 192 & Ttn-Fa & Pxd, II, Fa, Ttn & 1 \\
\hline$<1$ & $1000(3)$ & 192 & $\mathrm{Wo}_{50} \mathrm{Fs}_{50}-\mathrm{II}_{100}$ & Pxd, II, Fa? & 2 \\
\hline$<1$ & $900(10)$ & 816 & $\mathrm{Wo}_{50} \mathrm{Fs}_{50}-\mathrm{II}_{100}{ }^{*}$ & no change & 87 \\
\hline$<1$ & $900(10)$ & 816 & Ttn-Fa† & $\mathrm{Wo}_{48 \pm 1}, \mathrm{II}_{99 \pm 1}, \mathrm{Fa}$, Ttn & $88, \mathrm{C}$ \\
\hline$<1$ & 900 & 1084 & $\mathrm{Wo}_{50} \mathrm{FS}_{50}-\mathrm{II}_{100}$ & no change & 95 \\
\hline$<1$ & 900 & 1084 & 3Ttn-Fa & Hd, II, Ttn & $96, \mathrm{C}$ \\
\hline$<1$ & $800(10)$ & 1764 & $\mathrm{Wo}_{50} \mathrm{Fs}_{50}-\|_{100}{ }^{*}$ & no change & 83 \\
\hline$<1$ & $800(10)$ & 1764 & Ttn-Fa† & $\mathrm{Fa}, \mathrm{Ttn}$, growth of $\mathrm{Hd}$ and appearance of II & 84 \\
\hline$<1$ & $725(10)$ & 1056 & $\mathrm{Wo}_{50} \mathrm{FS}_{50}-\|_{100} *$ & $\mathrm{Hd}$, II & 85 \\
\hline$<1$ & $725(10)$ & 1056 & Ttn-Fat & $\mathrm{Fa}, \mathrm{Ttn}$, growth of $\mathrm{Hd}$ and appearance of II & 86 \\
\hline \multicolumn{6}{|c|}{ Experiments with the wüstite-magnetite (WM) buffer } \\
\hline $2000(10)$ & $800(10)$ & 21.5 & $\mathrm{Wo}_{50} \mathrm{Fs}_{50}-\mathrm{II}_{100}$ & no change; $W_{50 \pm 1}, \|_{99 \pm 1}$ & 10 \\
\hline $2000(10)$ & $800(10)$ & 21.5 & Ttn-Fa & $\mathrm{Wo}_{48 \pm 1}, \mathrm{II}_{98 \pm 2}, \mathrm{Fa}, \mathrm{Ttn}$ & $9, \mathrm{C}$ \\
\hline $2000(10)$ & $699(10)$ & 48 & $\mathrm{Wo}_{50} \mathrm{Fs}_{50}-I_{100}$ & no change; $\mathrm{Wo}_{49.5 \pm 1}, \mathrm{II}_{99 \pm 1}$ & 12 \\
\hline $2000(10)$ & $699(10)$ & 48 & Ttn-Fa & $\mathrm{Fa}, \mathrm{Ttn}, \mathbf{W o}_{47 \pm 2}, \mathrm{II}_{97 \pm 1}$ & $11, \mathrm{C}$ \\
\hline \multicolumn{6}{|c|}{ Experiments with the Co-cobalt oxide (CCO) buffer } \\
\hline $3400(20)$ & $750(10)$ & 3.5 & $\mathrm{Wo}_{50} \mathrm{Fs}_{50}-\mathrm{II}_{100}$ & no change & 91 \\
\hline $3400(20)$ & $750(10)$ & 3.5 & $3 \mathrm{Ttn}-\mathrm{Fa}$ & $\mathrm{Wo}_{42 \pm 2}, \mathrm{II}_{96 \pm 2,[96 \pm 1],}$ Ttn & $92, \mathrm{C}$ \\
\hline $2000(10)$ & $800(10)$ & 29.5 & $\mathrm{Wo}_{45} \mathrm{Fs}_{55}-\mathrm{Il}_{95}$ & no change, \|\|$_{94 \pm 1}$ & 89 \\
\hline $2000(10)$ & $800(10)$ & 29.5 & Ttn-Fa & $\mathrm{Wo}_{43 \pm 2}, \mathrm{II}_{96 \pm 2}$, Tth & $90, \mathrm{C}$ \\
\hline $2000(10)$ & $700(10)$ & 168 & $\mathrm{Wo}_{45} \mathrm{Fs}_{55}-\|_{100}$ & $\mathrm{Wo}_{45.5 \pm 1}, \mathrm{Il}, \mathrm{Fa} ? ?, \mathrm{Qz} ? ?$ & $13 a$ \\
\hline $2000(10)$ & $700(10)$ & 168 & Ttn-Fa & $\mathbf{W o}_{46 \pm 2}, \mathrm{II}_{94 \pm 2}, \mathrm{Ttn}, \mathrm{Fa}$ & $13 b, c$ \\
\hline $2000(10)$ & $657(10)$ & 524.5 & $\mathrm{Wo}_{45} \mathrm{Fs}_{55}-\|_{100}$ & no change & $14 \mathrm{a}$ \\
\hline $2000(10)$ & $657(10)$ & 524.5 & Ttn-Fa & Hd, II, Fa, Ttn & $14 b$ \\
\hline $2000(10)$ & $656(10)$ & 550 & $\mathrm{Wo}_{45} \mathrm{Fs}_{55}-\|_{100}$ & no change & 20 \\
\hline $2000(10)$ & 656(10) & 550 & Ttn-Fa & $\mathrm{Hd}, \mathrm{II}_{[96 \pm 1]}$, Ttn & 21 \\
\hline $2000(10)$ & $645(10)$ & 456 & $\mathrm{Wo}_{50} \mathrm{Fs}_{50}-\|_{100}$ & no change & 22 \\
\hline $2000(10)$ & $645(10)$ & 456 & Ttn-Fa & Hd, II ${ }_{[96 \pm 1]}, \mathrm{Fa}, \mathrm{Ttn}$ & 23 \\
\hline $2000(10)$ & $606(10)$ & 456 & $\mathrm{Wo}_{50} \mathrm{Fs}_{50}-\mathrm{II}_{100}$ & no change & 19 \\
\hline $2000(10)$ & $606(10)$ & 456 & Ttn-Fa & II, Fa, Ttn & 18 \\
\hline $2000(10)$ & $595(10)$ & 550 & $\mathrm{Wo}_{45} \mathrm{Fs}_{55}-\mathrm{II}_{100}$ & no change; $\mathrm{Wo}_{45.5 \pm 1}, \mathrm{II}_{100}$ & $15 a$ \\
\hline $2000(10)$ & $595(10)$ & 550 & Ttn-Fa & $\mathrm{Wo}_{46 \pm 2}, \mathrm{II}_{96 \pm 1,[97 \pm 1]}, \mathrm{Fa}, \mathrm{Ttn}$ & $15 b, C$ \\
\hline $1145(10)$ & 595(10) & 1360.5 & $\mathrm{Wo}_{45} \mathrm{Fs}_{55}-\mathrm{II}_{100}$ & $\mathrm{Hd}, \mathrm{II}, \mathrm{Qz} ?$ ? & 28 \\
\hline $1145(10)$ & $595(10)$ & 1360.5 & Ttn-Fa & Hd, II, Fa, Ttn & 29 \\
\hline \multicolumn{6}{|c|}{ 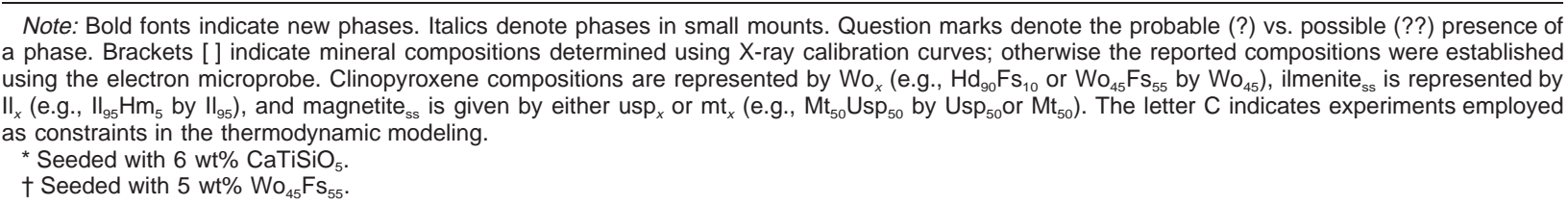 } \\
\hline
\end{tabular}

are shown in Figures 3, 4, 5, and 6. In all experiments the mechanical mixtures of $\mathrm{Ttn}+\mathrm{Fa}$ reacted to $\mathrm{Hd}_{\mathrm{ss}}$ (or pyroxenoid) $+\mathrm{Il}_{\mathrm{ss}}$. The grain size of the experimental products did not exceed $10 \mu \mathrm{m}$. At higher temperatures (i.e., dry: $\geq 900{ }^{\circ} \mathrm{C}$; hydrothermal: $\geq 700{ }^{\circ} \mathrm{C}$ ) $\mathrm{Hd}_{\mathrm{ss}}+\mathrm{Il}_{\mathrm{ss}}$ almost completely replaced $\mathrm{Ttn}+\mathrm{Fa}$. Less complete reaction was observed at lower temperatures, but nevertheless, the formation of $\mathrm{Hd}_{\mathrm{ss}}+\mathrm{Il}_{\mathrm{ss}}$ was clear. At $1000{ }^{\circ} \mathrm{C}$ and $<1$ atm, $\mathrm{Hd}_{\mathrm{ss}}$ partially transformed to pyroxenoid (ferrobustamite). Product $\mathrm{Hd}_{\mathrm{ss}}+\mathrm{Il}_{\mathrm{ss}}$ tended to form aggregates overgrowing either Ttn or Fa depending on the starting molar ratios of these phases. Mixtures of Ttn and Fa seeded with $\mathrm{Hd}_{\mathrm{ss}}$ also showed evidence of reaction: growth of the Hd peaks and appearance of Il peaks. In the mixtures seeded with Ttn grains, characteristic Ttn peaks [e.g., 111 , 200, 002, 202 ] either disappeared or decreased.

\section{Reaction 2}

The results for the equilibrium hedenbergite ${ }_{\mathrm{ss}}-$ ilmenite $_{\mathrm{ss}}-$ quartz-magnetite $_{\mathrm{ss}}$-titanite (HIQMT) are presented in Table 6 and all but two data points at 3.4 kbar 700 and 800
${ }^{\circ} \mathrm{C}$ (FMQ buffer) are depicted in Figures 3, 4, 5, and 6. The experimental results at $3.4 \mathrm{kbar}$ are identical to the ones at 3 and $3.8 \mathrm{kbar}$ (Fig. 6). At conditions where $\mathrm{Hd}_{\mathrm{ss}}+\mathrm{Il}_{\mathrm{ss}}$ and $\mathrm{Hd}+\mathrm{Il}$ mixtures reacted to $\mathrm{Ttn}+\mathrm{Mt}_{\mathrm{ss}}+\mathrm{Qz}$ the companion mixtures consisting of $\mathrm{Ttn}+\mathrm{Mt}_{\mathrm{ss}}+\mathrm{Qz}$ or $\mathrm{Ttn}+2 / 3 \mathrm{Mt}+\mathrm{Qz}$ produced either minor $\mathrm{Hd}_{\mathrm{ss}}$ or $\mathrm{Il}_{\mathrm{ss}}$ but never both. The presence of either $\mathrm{Hd}_{\mathrm{ss}}$ or $\mathrm{Il}_{\mathrm{ss}}$ depended on the Ti content of the Mt in the starting mechanical mixture. Where the original Mt contained no Ti, Hd was observed to contain $\mathrm{Qz}$ inclusions and to be in contact with grains of $\mathrm{Mt}_{\mathrm{ss}}$ and $\mathrm{Ttn}$. If the original Mt was titaniferous, then Il was dispersed in the matrix but only close to grains of $\mathrm{Mt}_{\mathrm{ss}}$. In contrast, where $\mathrm{Hd}_{\mathrm{ss}}$ and $\mathrm{Il}_{\mathrm{ss}}$ grew at the expense of $\mathrm{Ttn}+\mathrm{Mt}_{\mathrm{ss}}+\mathrm{Qz}$, or $\mathrm{Ttn}+2 / 3 \mathrm{Mt}+\mathrm{Qz}$, the companion mixtures of $\mathrm{Hd}+\mathrm{Il}$ and $\mathrm{Hd}_{\mathrm{ss}}+\mathrm{Il}_{\mathrm{ss}}$ did not change.

At $P<1$ atm, the phase relations are complicated by the transformation of quartz to tridymite at $T>900{ }^{\circ} \mathrm{C}$, by partial conversion of end-member hedenbergite and hedenbergite $_{\text {ss }}$ to pyroxenoid at $T \geq 940{ }^{\circ} \mathrm{C}$, and by partial melting at $T \geq 1050 \pm 10{ }^{\circ} \mathrm{C}$. Nevertheless, at $T \geq 800$ ${ }^{\circ} \mathrm{C}$ (FMQ buffer) and at $T \geq 940{ }^{\circ} \mathrm{C}$ (Co-CoO buffer), the 


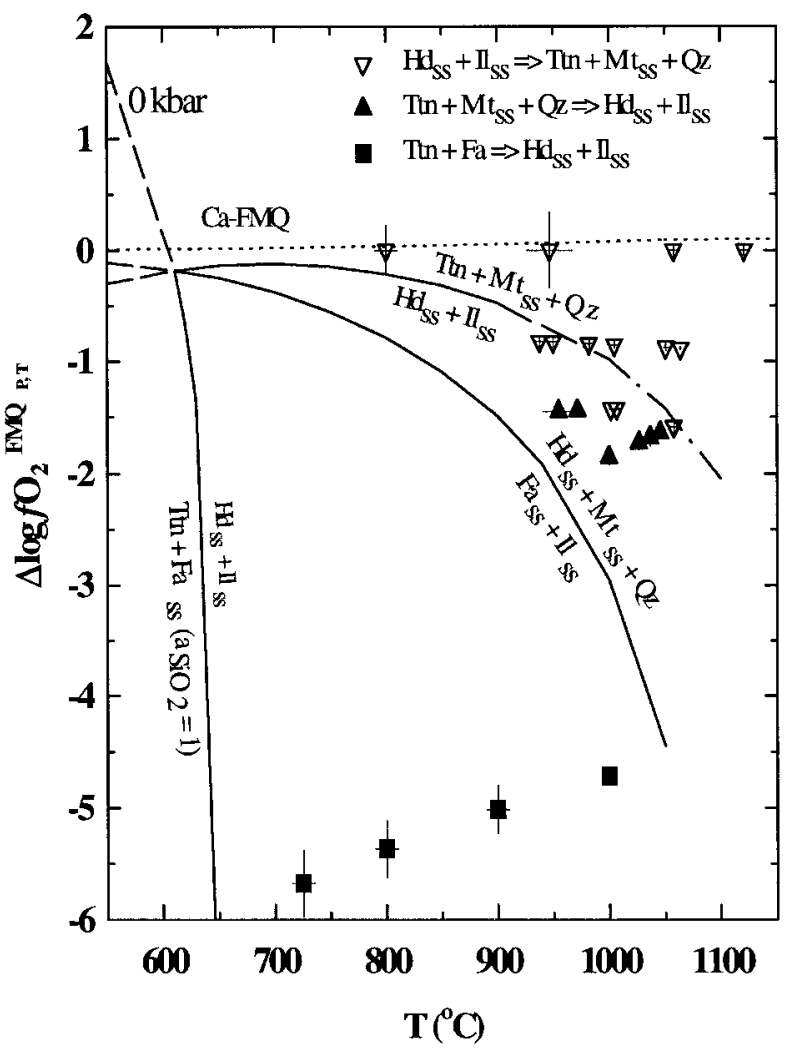

FigURE 3. $\Delta \log f_{\mathrm{O}_{2}}^{(\mathrm{FMQ}} 1, *$ bar, $\left.T\right)-T$ plot of experimental results at 0 kbar and calculated phase relations among Ttn, $\mathrm{Hd}_{\mathrm{ss}}, \mathrm{Fa}_{\mathrm{ss}}, \mathrm{Il}_{\mathrm{ss}}$, $\mathrm{Mt}_{\mathrm{ss}}$, and $\mathrm{Qz}$ with the derived thermodynamic data for titanite. Dashed lines represent the metastable extensions of the calculated reactions. At $T \geq 940{ }^{\circ} \mathrm{C}$ the dashed-dotted line represents the calculated metastable extension of the isobarically univariant assemblage $\mathrm{Ttn}+\mathrm{Mt}_{\mathrm{ss}}+$ Cristobalite $+\mathrm{Il}_{\mathrm{ss}}+\mathrm{Hd}_{\mathrm{ss}}$. See text for discussion.

stable assemblage is titanite, magnetite ${ }_{\text {ss }}$, and the stable silica polymorph. At lower $f_{\mathrm{O}_{2}}$ conditions, those of the $\mathrm{Co}-\mathrm{SiO}_{2}-\mathrm{Co}_{2} \mathrm{SiO}_{4}$ buffer at $T<1000{ }^{\circ} \mathrm{C}$ and $\mathrm{WM}$ at $T<$ $1050{ }^{\circ} \mathrm{C}$, pyroxenoid and ilmenite ${ }_{\mathrm{ss}}$ are stable. Starting mechanical mixtures containing either pyroxenoid or tridymite were not used. However, powder XRD suggests that the transformation of hedenbergite or hedenbergite ${ }_{\mathrm{ss}}$ to pyroxenoid, and quartz to tridymite, was mostly complete after equilibration. At higher pressures where the rest of the experiments were performed these complications were avoided.

The experimental results suggest that at 1 to $2 \mathrm{kbar}$ and 600 to $800{ }^{\circ} \mathrm{C}$ reaction 2 is located between the FMQ and $\mathrm{Co}-\mathrm{CoO}$ buffer curves whereas at $\geq 3 \mathrm{kbar}$ and 675 to $750{ }^{\circ} \mathrm{C}$ it lies above the FMQ buffer curve.

\section{Discussion}

The technique of mathematical programming (Berman et al. 1986; Berman 1988) was employed to derive thermodynamic data for titanite consistent with the phase equilibrium and calorimetry experiments (Xirouchakis et

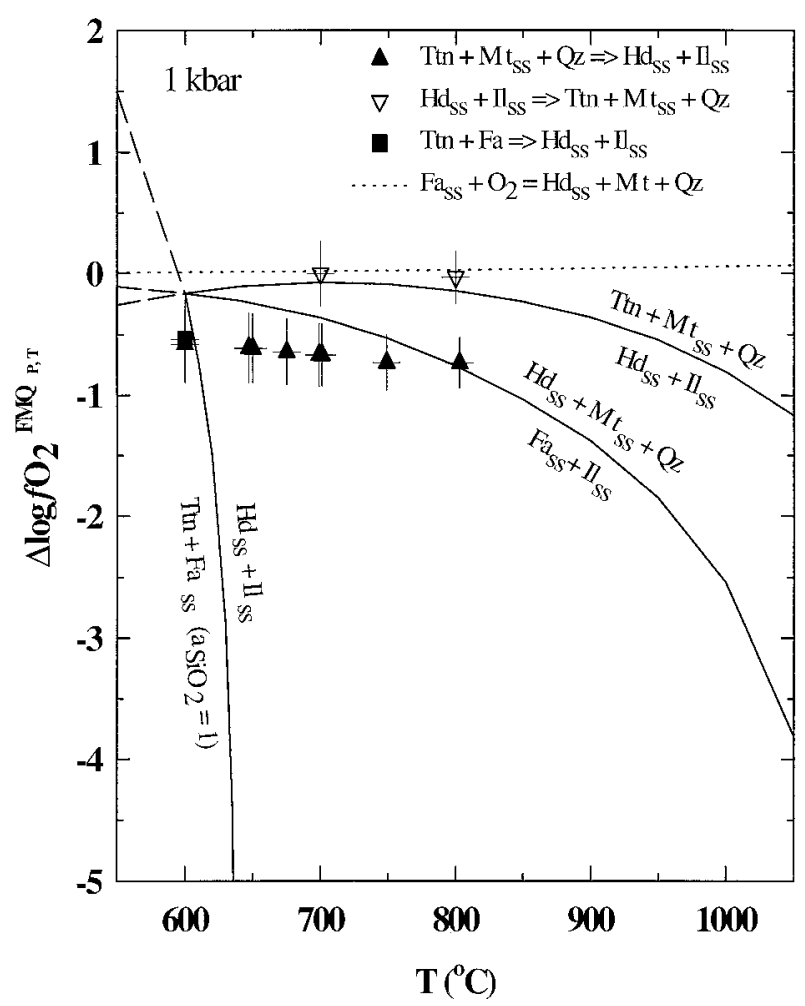

Figure 4. $\Delta \log f_{\mathrm{O}_{2}}^{(\mathrm{MQ}} 1$ bar, $\left.T\right)-T$ plot of experimental results at 1 kbar and calculated phase relations among Ttn, $\mathrm{Hd}_{\mathrm{ss}}, \mathrm{Fa}_{\mathrm{ss}}, \mathrm{Il}_{\mathrm{ss}}$, $\mathrm{Mt}_{\mathrm{ss}}$, and $\mathrm{Qz}$ with the preferred thermodynamic data for titanite. Dashed lines represent the metastable extensions of the calculated reactions.

al. 1996b, 1997b). This technique was deemed most appropriate because many of the experimental constraints are only half-reversals (i.e., reaction 1). Moreover, experimental data inconsistent with the thermodynamic model of choice can be identified. However, this approach is not without drawbacks. Formal uncertainties cannot be assigned to the optimized parameters and, in many cases, the solution obtained is an element on the boundary of the feasible solution set (Olbricht et al. 1994). Nonetheless, in this context each phase-equilibrium experiment represents a change in the Gibbs free energy for a given reaction $r$ that can be expressed in terms of phase components by the inequality:

$$
\Delta G_{r}=\sum_{1}^{n} v_{i}^{j} \cdot \mu_{i}^{j} \leq 0
$$

(e.g., Gordon 1973; Day and Kumin 1980; Berman et al. 1986). In the above relation $\nu_{j}^{j}$ and $\mu_{i}^{j}$, respectively, denote the stoichiometric coefficient and the chemical potential of the $i^{\text {th }}$ component in the $j^{\text {th }}$ phase defined by the equation: 


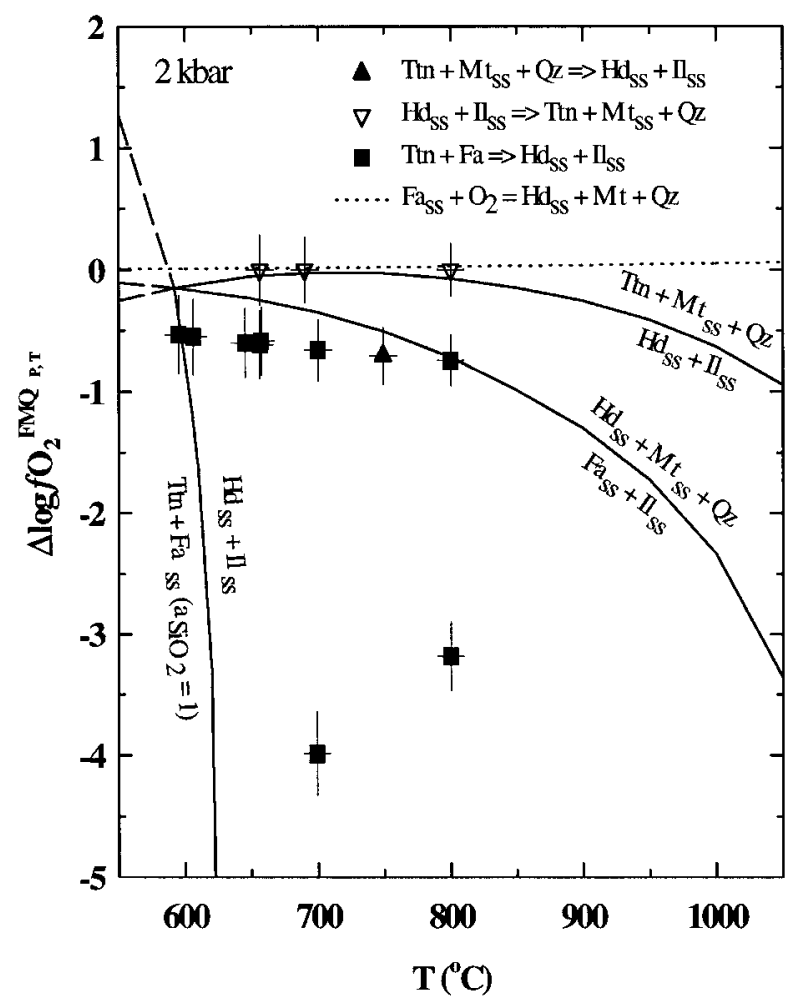

Figure 5. $\Delta \log f_{\mathrm{O}_{2}}^{(\mathrm{FM} 1 \mathrm{Bar}, T)}-T$ plot of experimental results at 2 kbar and calculated phase relations among $\mathrm{Ttn}, \mathrm{Hd}_{\mathrm{ss}}, \mathrm{Fa}_{\mathrm{ss}}, \mathrm{Il}_{\mathrm{ss}}$, $\mathrm{Mt}_{\mathrm{ss}}$, and Qz with the preferred thermodynamic data for titanite. Dashed lines represent the metastable extensions of the calculated reactions.

$$
\begin{aligned}
\mu_{i}^{j}= & \Delta H_{i, T_{\mathrm{r}}, P_{\mathrm{r}}}^{0, j}-T \cdot S_{i, T_{\mathrm{r}}, P_{\mathrm{r}}}^{0, j}+\int_{T_{\mathrm{r}}}^{T} C_{\mathrm{p}} \mathrm{d} T-T \cdot \int_{T_{\mathrm{r}}}^{T} \frac{C_{\mathrm{p}}}{T} \mathrm{~d} T \\
& +\int_{P_{\mathrm{r}}}^{P} V_{i, T, P}^{0, j} \mathrm{~d} P+R \cdot T \cdot \ln a_{i}^{j}
\end{aligned}
$$

where $\Delta H^{0}$ and $S^{0}$ are the standard state molar enthalpy and entropy of formation of component $i$ in phase $j$ from the elements at the reference temperature $\left(T_{\mathrm{r}}\right)$ and pressure $\left(P_{\mathrm{r}}\right) ; C_{\mathrm{p}}$ and $V_{\mathrm{i}, \text { PT }}$ are the molar heat capacity function and molar volume at $T$ and $P$, respectively; and $a_{\mathrm{i}}$ is the activity of component $i$ in phase $j$.

To evaluate Equation 8, standard state thermodynamic data and activity expressions for the solid-solution phases are needed. Thus it is necessary to select a thermodynamic database as a starting point. Almost any internally consistent database should be suitable. For example, we could have used the database of Berman $(1988,1991)$ as augmented by the oxide and pyroxene-olivine models of Ghiorso (1990) and Ghiorso and Sack (1991), and Sack and Ghiorso (1994a, 1994b, 1989), respectively, or the database of Holland and Powell (1990) if solution models internally consistent with it existed. We have chosen instead to adopt the QUIIF database, which comprises the silicate model of Davidson and Lindsley (1989), the Fe-
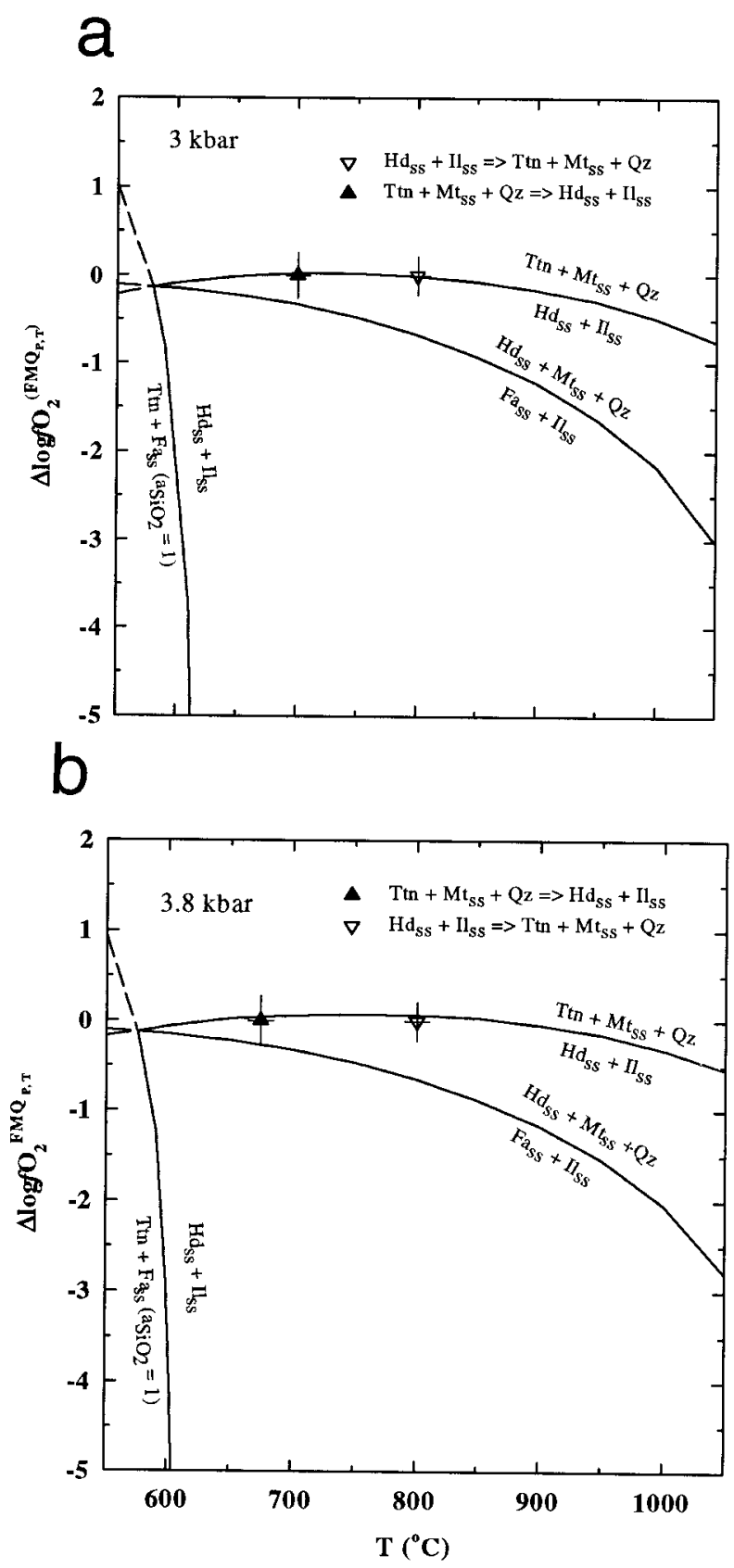

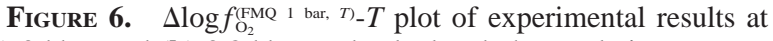
(a) $3 \mathrm{kbar}$ and (b) $3.8 \mathrm{kbar}$ and calculated phase relations among $\mathrm{Ttn}, \mathrm{Hd}_{\mathrm{ss}}, \mathrm{Fa}_{\mathrm{ss}}, \mathrm{Il}_{\mathrm{ss}}, \mathrm{Mt}_{\mathrm{ss}}$, and Qz with the preferred thermodynamic data for titanite. Dashed lines represent the metastable extensions of the calculated reactions.

Ti oxides model of Andersen and Lindsley (1988), and the combination of these into the "QUIlF" model (Frost et al. 1988; Lindsley and Frost 1992; Frost and Lindsley 1992; Andersen et al. 1993). Relative to the Ghiorso and Sack (1990; 1991) oxide model, the Andersen and Lindsley model (1988) more successfully reproduces the experimental results for $\mathrm{Fe}-\mathrm{Ti}$ oxides at $600-700{ }^{\circ} \mathrm{C}$, a key 
range for the present study. Most importantly, use of the QUIIF database permits relatively straightforward incorporation of the new titanite data into the widely used "QUILF" program (Andersen et al. 1993). The only modification was the addition of thermal expansivity and compressibility terms for ilmenite $\left(\mathrm{FeTiO}_{3}\right)$ from a leastsquares fit to the data of Wechsler and Prewitt (1984).

The adoption of the QUIIF database entails certain consequences. The oxide model and the combined oxide-silicate model were based on the unpublished data of Haas (personal communication to D.H.L.; see also discussion in Lindsley and Frost 1992, p. 988) for oxygen buffers, which were revised and reissued by Haas and Hemingway (1992). Thus a key decision was whether to incorporate the newer buffer data, which would involve remodeling both the oxide and the silicate portion of the "QUILF" model, a major undertaking. The actual differences between the 1986 and 1992 buffer data are small, between 500-1000 J/mol. Trial calculations indicated that remodeling the older data would result in negligibly small changes (well within the experimental uncertainty) in the oxide and the silicate models. Accordingly we decided to retain the older database in our calculations. To facilitate the inclusion of the derived thermodynamic data for titanite to the QUILF program the empirical heat capacity polynomial of Haas (personal communication to D.H.L.; see also discussion in Lindsley and Frost 1992, p. 988) and Haas and Hemingway (1992)

$$
C_{\mathrm{p}}=\frac{a_{1}}{T^{3}}+\frac{a_{2}}{T^{2}}+\frac{a_{3}}{T}+\frac{a_{4}}{\sqrt{T}}+a_{5}+a_{6} \cdot T+a_{7} \cdot T^{2},
$$

and the volume equation of Robinson et al. (1982)

$$
V_{T, P}^{0}=b_{1}+b_{2} \cdot T+b_{3} \cdot e^{(-T / 300)}+b_{4} \cdot P+b_{5} \cdot e^{(-P / 35000)}
$$

were used in the calculations where $T$ is in kelvins and $P$ in bars. Despite its apparent complexity, Equation 9 is quite flexible and can be transformed to the heat capacity polynomials proposed by Haas and Fisher (1976) and Berman and Brown (1985). The standard state molar volume of titanite was taken from Xirouchakis et al. (1997a). The thermal expansivity and compressibility parameters were derived from nonlinear regression of unit-cell volume measurements at ambient pressure and up to 1000 ${ }^{\circ} \mathrm{C}$ (Taylor and Brown 1976), and at room temperature from 1 atm up to $70 \mathrm{kbar}$ (Kunz et al. 1996; Angel et al., unpublished manuscript). Thus for a molar volume of $5.560 \pm 0.002 \mathrm{~J} / \mathrm{bar}$ the thermal expansivity $(1 / \mathrm{K})$ and compressibility parameters (1/bar) are: $b_{1}=5.497705, b_{2}$ $=1.48606 \times 10^{-4}, b_{3}=4.8950 \times 10^{-2}, b_{4}=-4.01012$ $\times 10^{-6}$, and $b_{5}=4.730 \times 10^{-2}$. The data of Taylor and Brown (1976) were preferred, despite the relatively high unit-cell volume of their sample, because their measurements agree better than the data of Ghose et al. (1991) with the data of Hughes et al. (1997) and Xirouchakis et al. (1997a) for end-member titanite at room pressure and temperature. Like the Ghose et al. (1991) titanite sample, the crystal used by Zhang et al. (1995) has a suspiciously large unit-cell volume and it apparently contains wollas- tonite and quartz impurities (Tanaka et al. 1988). Thus, the high-temperature heat capacity data of Zhang et al. (1995) were also avoided.

Once standard-state thermodynamic data and solution models were adopted, then the thermochemical properties of titanite could be constrained by the inequalities

$$
\begin{array}{r}
\mu_{\mathrm{CaFeSi}_{2} \mathrm{O}_{6}}^{\mathrm{hdss}}+\mu_{\mathrm{FeTiO}_{3}}^{\mathrm{ilss}_{\mathrm{Se}}}-\mu_{\mathrm{CaTiSiO}_{5}}^{\mathrm{Ttn}}-\mu_{\mathrm{Fe}_{2} \mathrm{SiO}_{4}}^{\mathrm{fa}} \leq 0 \\
3 \mu_{\mathrm{CaFeS}_{2} \mathrm{O}_{6}}^{\mathrm{hds}}+3 \mu_{\mathrm{FeTiO}_{3}}^{\mathrm{ilss}}+\mu_{\mathrm{O}_{2}}-3 \mu_{\mathrm{CaTiSiO}_{5}}^{\mathrm{Ttn}}-2 \mu_{\mathrm{Fe}_{3} \mathrm{O}_{4}}^{\mathrm{mtss}} \\
-3 \mu_{\mathrm{SiO}_{2}}^{\mathrm{qz}} \leq, \geq 0 .
\end{array}
$$

Experiments at $T>900{ }^{\circ} \mathrm{C}$ and $<1$ atm were not included because of polymorphic changes, i.e., quartz to tridymite, and most importantly clinopyroxene to pyroxenoid. The uncertainties in pressure, temperature, oxygen fugacity, and the composition of the minerals were incorporated in the calculations by considering all possible combinations of their numerical values. Thus, the uncertainty ellipsoid of each datum (Clifford 1973) is approximated empirically as a range in $\Delta G_{\mathrm{r}}$ values that were considered simultaneously in the linear programming problem for all the constraints. The experimental data considered in the thermodynamic modeling, a total of sixteen experiments, are marked by the letter $\mathrm{C}$ in Tables 5 and 6 . Further constraints on the standard-state enthalpy of formation of titanite come from the most recent calorimetric study (Xirouchakis et al. 1997b). Under the conditions of the calorimetry and phase-equilibrium experiments, titanite has the high-temperature structure $(A 2 / a)$. Except for the molar volume, the rest of the available data and constraints are also for the high-temperature phase. Thus, the $P 2_{1} / a$ to $A 2 / a$ transition in titanite (Taylor and Brown 1976; Kunz et al. 1996) was not considered, and it was assumed that the properties of titanite can be described effectively with the same equation of state above and below the transition.

Reaction and calorimetry constraints were considered simultaneously in conjunction with the following objective function:

$$
F=\sum_{1}^{n} \frac{\left(Y_{\text {obs }}-Y_{\text {calc }}\right)^{2}}{\left|Y_{\text {calc }}\right|}
$$

which minimizes the difference between calculated and measured quantities (Taylor 1982; Grace 1990). Agreement between an enthalpy of formation of $-2610.13 \pm$ $2.90 \mathrm{~kJ} / \mathrm{mol}$ (Xirouchakis et al. 1997b) and the phaseequilibrium constraints of this study required the simultaneous optimization of heat capacity equation terms. The final optimized parameters for titanite were chosen based on the agreement between calculated and experimentally determined phase relations and the behavior of the $C_{\mathrm{p}}(T)$ and $\left(H_{\mathrm{T}}-H_{298}\right)$ functions at high temperatures.

The heat capacity polynomial coefficients were optimized by minimizing the discrepancy between the calculated and measured heat content $\left(H_{\mathrm{T}}-H_{298}\right)$ at $702{ }^{\circ} \mathrm{C}$ $(122.985 \mathrm{~kJ} / \mathrm{mol})$. The latter value was obtained from the difference of the enthalpy of drop solution and prelimi- 
TABLE 6. Reaction 2: experiments with the wüstite-magnetite (WM) buffer

\begin{tabular}{|c|c|c|c|c|c|}
\hline$P$ (bar) & $T\left({ }^{\circ} \mathrm{C}\right)$ & $\begin{array}{l}\text { Duration } \\
\text { (h) }\end{array}$ & Reactants & Products & Experiment no. \\
\hline$<1$ & 1058(3) & 66 & $\mathrm{Wo}_{50} \mathrm{Fs}_{50}-\|_{100}$ & Ttn, glass, Usp $\mathrm{p}_{[85 ? ?]}, \mathrm{Pxd}, \|$ & 79 \\
\hline$<1$ & $1058(3)$ & 66 & Ttn-Usp $p_{60}-Q z$ & Ttn, Trid, Usp ${ }_{[85 ? ?]}$, glass, Pxd? & 80 \\
\hline$<1$ & $1046(3)$ & 157 & $\mathrm{Wo}_{50} \mathrm{Fs}_{50}-\|_{100}$ & Pxd, II, glass? & 87 \\
\hline$<1$ & $1046(3)$ & 157 & Ttn-Usp ${ }_{60}-Q z$ & Pxd, II, Ttn, Usp ${ }_{[60]}$, glass? & 88 \\
\hline$<1$ & $1037(4)$ & 184 & $\mathrm{Wo}_{50} \mathrm{Fs}_{50}-2 \mathrm{II}_{100}$ & Pxd, II & 85 \\
\hline$<1$ & $1037(4)$ & 184 & Ttn-Usp $60-Q z$ & Pxd, II & 86 \\
\hline$<1$ & $1027(3)$ & 63 & $\mathrm{Wo}_{50} \mathrm{Fs}_{50}-\|_{100}$ & Pxd, II & 83 \\
\hline$<1$ & $1027(3)$ & 63 & Ttn-Usp ${ }_{60}-\mathrm{Qz}$ & Pxd, II, Trid?, Usp & 84 \\
\hline$<1$ & $1000(3)$ & 43.5 & $\mathrm{Wo}_{50} \mathrm{FS}_{50}-\mathrm{II}_{100}$ & Pxd, II & 68 \\
\hline$<1$ & $1000(3)$ & 43.5 & $\mathrm{Ttn}-2 / 3 \mathrm{Mt}-\mathrm{Qz}$ & Pxd, II, Ttn, $\mathrm{Mt}_{\mathrm{ss}}$ ?, Trid & 69 \\
\hline \multicolumn{6}{|c|}{ Experiments with the Co-quartz- $\mathrm{Co}_{2} \mathrm{SiO}_{4}(\mathrm{CoQzOI})$ buffer } \\
\hline$<1$ & $1007(2)$ & 90.5 & $\mathrm{Wo}_{50} \mathrm{Fs}_{50}-\|_{100}$ & Ttn, Trid, Usp ${ }_{[70 \pm 5]}, P x d, / /$ & 54 \\
\hline$<1$ & $1007(2)$ & 90.5 & Ttn-Mt-Qz & Ttn, Trid, Usp $[70 \pm 5]$, Pxd & 55 \\
\hline$<1$ & $1002(2)$ & 118 & $\mathrm{Wo}_{50} \mathrm{Fs}_{50}-\mathrm{II}_{100}$ & Ttn, Trid, Usp ${ }_{[80 ? ?]}, H d / P x d$ & 72 \\
\hline$<1$ & $1002(2)$ & 118 & Ttn-Mt-Qz & Ttn, Usp ${ }_{[80 ?]}$, Trid/Qz, Pxd & 73 \\
\hline$<1$ & $972(2)$ & 159.5 & $\mathrm{Wo}_{50} \mathrm{Fs}_{50}-2 \mathrm{II}_{100}$ & Pxd, II, Trid?? & 97 \\
\hline$<1$ & $972(2)$ & 159.5 & Ttn-Usp $80-Q z$ & Pxd, $\|_{[99 \pm 1]}$, Ttn, Trid & 98 \\
\hline$<1$ & $955(14)$ & 237 & $\mathrm{Wo}_{50} \mathrm{Fs}_{50}-\|_{100}$ & Pxd, II, Trid?? & 89 \\
\hline$<1$ & $955(14)$ & 237 & Ttn-Usp $60-Q z$ & Pxd, $\|_{[99 \pm 1]}$, Ttn, Trid, $U_{s p_{[60]}} ?$ & 90 \\
\hline \multicolumn{6}{|c|}{ Experiments with the Co-CoO (CCO) buffer } \\
\hline$<1$ & $1064(1)$ & 144 & $\mathrm{Wo}_{45} \mathrm{Fs}_{55}-\|_{100}$ & Ttn, Trid, Usp ${ }_{[70 \pm 5]}$, glass, $P x d$ & 39 \\
\hline$<1$ & 1064(1) & 144 & Ttn-Mt-Qz & Ttn, Trid, Usp ${ }_{[70 \pm 5]}$, Pxd, glass & 40 \\
\hline$<1$ & $1051(2)$ & 186 & $\mathrm{Wo}_{45} \mathrm{Fs}_{55}-\mathrm{II}_{100}$ & Ttn, Trid, Usp ${ }_{[70 \pm 5]}$, glass, Pxd & 52 \\
\hline$<1$ & $1051(2)$ & 186 & Ttn-Mt-Qz & Ttn, Usp ${ }_{[70 \pm 5]}$, Trid, Pxd, glass & 53 \\
\hline$<1$ & $1005(2)$ & 186 & $\mathrm{Wo}_{45} \mathrm{FS}_{55}-\|_{100}$ & Ttn, Usp & 50 \\
\hline$<1$ & $1005(2)$ & 186 & Ttn-Mt-Qz & Ttn, Usp ${ }_{[70 \pm 5]}$, Trid, $H d / P x d$ & 51 \\
\hline$<1$ & $938(3)$ & 183 & $\mathrm{Wo}_{50} \mathrm{Fs}_{50}-\mathrm{II}_{100}$ & Ttn, Usp ${ }_{[62 \pm 5]}$, Trid?, Hd & 91 \\
\hline$<1$ & $938(3)$ & 183 & Ttn-Usp $p_{60}-\mathrm{Qz}$ & Ttn, Usp ${ }_{[60]}$, Trid, $H d ?$ & 92 \\
\hline$<1$ & $982(4)$ & 428 & $\mathrm{Wo}_{50} \mathrm{FS}_{50}-\|_{100}$ & Ttn, Usp ${ }_{[62 \pm 5]}$, Trid, $H d / P x d ?$ & 76 \\
\hline$<1$ & $982(4)$ & 428 & Ttn-Usp $\mathrm{s0}_{60}-\mathrm{Qz}$ & Ttn, Usp $[60],{ }^{62 \pm 19} / \mathrm{Qz}$ & 77 \\
\hline$<1$ & $950(3)$ & 424.5 & $\mathrm{Wo}_{50} \mathrm{FS}_{50}-\mathrm{II}_{100}$ & Ttn, Usp & 74 \\
\hline$<1$ & $950(3)$ & 424.5 & Ttn-Usp $\mathrm{s0}_{60}-\mathrm{Qz}$ & Ttn, Usp 60, Trid/Qz & 75 \\
\hline $1985(10)$ & $749(10)$ & 95.5 & $\mathrm{Wo}_{45} \mathrm{FS}_{55}-\mathrm{II}_{90}$ & $\mathrm{Wo}_{46 \pm 2}, I_{90 \pm 2}, U_{s p_{47 \pm 3}}$ & 60 \\
\hline 1985(10) & $749(10)$ & 95.5 & Ttn-Usp $p_{50}-Q z$ & $\mathrm{Wo}_{44 \pm 2}, \mathrm{II}_{95 \pm 1}$ & $61, \mathrm{C}$ \\
\hline $1145(10)$ & $675(10)$ & 428.5 & $\mathrm{Wo}_{50} \mathrm{Fs}_{50}-\mathrm{II}_{100}$ & no change & 27 \\
\hline 1145(10) & $675(10)$ & 428.5 & $\mathrm{Ttn}-2 / 3 \mathrm{Mt}-\mathrm{Qz}$ & $\mathrm{Wo}_{[43 \pm 3]}, \mathrm{II}_{[94 \pm 2]}$, Ttn, Usp ${ }_{[15 ?]}, Q z$ & 28 \\
\hline $1145(10)$ & $650(10)$ & 432 & $\mathrm{Wo}_{45} \mathrm{Fs}_{55}-\mathrm{II}_{100}$ & no change & 25 \\
\hline $1145(10)$ & $650(10)$ & 432 & Ttn- $2 / 3 \mathrm{Mt}-\mathrm{Qz}$ & $\mathrm{Wo}_{[44 \pm 2]}, \mathrm{II}_{[94 \pm 2]}$, Ttn, $M t_{s s}$ ?, Qz & 26 \\
\hline $1145(10)$ & $599(10)$ & 616.5 & $\mathrm{Wo}_{45} \mathrm{Fs}_{55}-\mathrm{II}_{100}$ & no change & 29 \\
\hline $1145(10)$ & $599(10)$ & 616.5 & Ttn- $2 / 3 \mathrm{Mt}-\mathrm{Qz}$ & $\mathrm{Wo}_{[43 \pm 3]}, \mathrm{II}_{[97 \pm 2]}$, Ttn, $M t_{s s}$ ? & 30 \\
\hline $1001(10)$ & $701(10)$ & 409 & $\mathrm{Wo}_{45} \mathrm{Fs}_{55}-\mathrm{II}_{90}$ & no change & 62 \\
\hline $1001(10)$ & $701(10)$ & 409 & Ttn-Usp $p_{50}-Q z$ & $\mathrm{Wo}_{[45 \pm 3]}, \mathrm{II}_{95 \pm 2,[93 \pm 2]}, T$ th, $Q z$ & $63, \mathrm{C}$ \\
\hline $1020(10)$ & $699(10)$ & 720 & $\mathrm{Wo}_{50} \mathrm{FS}_{50}-\mathrm{II}_{100}$ & $\mathrm{Hd}, \| \mathrm{I}, \mathrm{Qz} ?$ ? & 9 \\
\hline $1020(10)$ & $699(10)$ & 720 & $\mathrm{Ttn}-2 / 3 \mathrm{Mt}-\mathrm{Qz}$ & $\mathrm{Wo}_{45 \pm 3,[45 \pm 5]}, \mathrm{II}_{94 \pm 1,[96 \pm 3]}$, Tth, $U_{s p_{[50 \pm 5]}, Q z}$ & 10 \\
\hline $1002(8)$ & $803(10)$ & 95.5 & $\mathrm{Wo}_{45} \mathrm{Fs}_{55}-\mathrm{II}_{90}$ & no change; $W_{46 \pm 2}, \|_{89 \pm 2}$ & 58 \\
\hline $1002(8)$ & $803(10)$ & 95.5 & Ttn-Usp $p_{50}-Q z$ & $\mathrm{Wo}_{[44 \pm 3]}, \mathrm{II}_{95 \pm 1,[95 \pm 2]}, \mathrm{Ttn}, \mathrm{Mt} \mathrm{t}_{s s}$ ? & $59, \mathrm{C}$ \\
\hline $1000(10)$ & $647(10)$ & 621 & $\mathrm{Wo}_{45} \mathrm{FS}_{55}-\mathrm{II}_{100}$ & no change & 48 \\
\hline $1000(10)$ & $647(10)$ & 621 & $\mathrm{Ttn}-2 / 3 \mathrm{Mt}-\mathrm{Qz}$ & $\mathrm{Wo}_{[44 \pm 2]}, \mathrm{II}_{[93 \pm 3]}$, Ttn, Usp $p_{[20]} ?, Q z$ & 49 \\
\hline \multicolumn{6}{|c|}{ Experiments with the fayalite-magnetite-quartz (FMQ) buffer } \\
\hline$<1$ & $1121(4)$ & 4 & $\mathrm{Wo}_{45} \mathrm{Fs}_{55}-\|_{100}$ & Ttn, $\mathbf{M t}_{\mathrm{ss}}$, Trid, glass, $\|, \mathrm{Pxd}$ ? & 37 \\
\hline$<1$ & $1121(4)$ & 4 & Ttn-Mt-Qz & Ttn, Trid, $\mathrm{Mt}_{\mathrm{ss}}$, glass, Pxd? & 38 \\
\hline$<1$ & $1058(4)$ & 124 & $\mathrm{Wo}_{45} \mathrm{FS}_{55}-\mathrm{II}_{100}$ & Ttn, Usp ${ }_{[65 \pm 5]}$, Trid, Hd/Pxd & 31 \\
\hline$<1$ & $1058(4)$ & 124 & Ttn-Mt-Qz & Ttn, Usp ${ }_{[65 \pm 5]}$, Trid, $P x d$ & 32 \\
\hline$<1$ & $947(20)$ & 478 & $\mathrm{Wo}_{45} \mathrm{FS}_{55}-\mathrm{II}_{95}$ & Ttn, Usp ${ }_{[58 \pm 5}$, Trid, $\mathrm{Hd} /(\mathrm{Pxd}$ ?), // & 141 \\
\hline$<1$ & $947(20)$ & 478 & $\mathrm{Ttn}-2 / 3 \mathrm{Mt}-\mathrm{Qz}$ & Ttn, Usp ${ }_{[55 \pm 5]}^{[55 \pm 5]}$, Trid, $P x d$ & 142 \\
\hline$<1$ & $800(10)$ & 1052 & $\mathrm{Wo}_{50} \mathrm{Fs}_{50}-\mathrm{II}_{100} \dagger$ & Hd, II, growth of Ttn, Usp $p_{46 \pm 1}, Q z ?$ & $145, \mathrm{C}$ \\
\hline$<1$ & $800(10)$ & 1052 & $\mathrm{Ttn}^{2} / 3 \mathrm{Mt}-\mathrm{Qz}$ & Ttn, Usp ${ }_{[40+5]}, \mathrm{Qz}, \mathrm{Hd}$ & 146 \\
\hline $3800(10)$ & $674(10)$ & 72 & $\mathrm{Wo}_{50} \mathrm{Fs}_{50}-\mathrm{II}_{100}$ & no change & 107 \\
\hline $3800(10)$ & $674(10)$ & 72 & $\mathrm{Ttn}-2 / 3 \mathrm{Mt}-\mathrm{Qz}$ & $\mathbf{W o}_{44 \pm 2,[41 \pm 3]}, \mathbf{I I}_{[92 \pm 5]}$, Tth, $Q z$ & 108 \\
\hline $3700(30)$ & $800(10)$ & 9.5 & $\mathrm{Wo}_{50} \mathrm{Fs}_{50}-\mathrm{II}_{100}$ & Ttn, Usp ${ }_{[35 \pm 5]}, \mathbf{Q z}, H d$ & $113, \mathrm{C}$ \\
\hline $3700(30)$ & $800(10)$ & 9.5 & $\mathrm{Ttn}-2 / 3 \mathrm{Mt}-\mathrm{Qz}$ & Ttn, Usp ${ }_{[40 \pm 5]}, \mathrm{Qz}, \mathrm{Hd}$ & 114 \\
\hline $3410(10)$ & $750(10)$ & 89 & $\mathrm{Wo}_{45} \mathrm{FS}_{55}-\mathrm{II}_{95}$ & no change & $115 B$ \\
\hline $3410(10)$ & $750(10)$ & 89 & Ttn-2/3Mt-Qz & $\mathbf{W o}_{44+1,[44+3]}, \mathbf{I I}_{92+1,93+1]}, T t n, Q z, U_{s p_{[37+5]}}$ & $116 B$ \\
\hline $3410(10)$ & $700(10)$ & 355 & $\mathrm{Wo}_{45} \mathrm{FS}_{55}-\mathrm{II}_{95}$ & $\begin{array}{l}\text { no change, } Q z ? \\
\text { no }\end{array}$ & 117 \\
\hline $3410(10)$ & $700(10)$ & 355 & Ttn-2/3Mt-Qz & Wo $_{[44 \pm 3]}, \mathrm{II}_{[96 \pm 3]}$, Ttn, $U_{s p_{[25+33}, Q z}$ & 118 \\
\hline $3010(10)$ & $800(10)$ & 12 & $\mathrm{Wo}_{45} \mathrm{FS}_{55}-\mathrm{II}_{100}$ & $\mathrm{Hd}$, II, appearance and growth of $\mathrm{Ttn}, \mathrm{Mt}_{\mathrm{ss}}$ & 129 \\
\hline $3010(10)$ & $800(10)$ & 12 & $\mathrm{Ttn}-2 / 3 \mathrm{Mt}-\mathrm{Qz}$ & Ttn, Usp ${ }_{[38+3]}, \mathrm{Qz}, \mathrm{Hd}$ & 130 \\
\hline $3000(10)$ & $700(10)$ & 381 & $\mathrm{Wo}_{45} \mathrm{Fs}_{55}-3 \mathrm{II}_{95}$ & $\mathrm{Hd}, \mathrm{II}, M t_{s s}, Q z$ & 147 \\
\hline $3000(10)$ & $700(10)$ & 381 & Ttn-Usp $p_{25}-\mathrm{Qz}$ & $\mathbf{W o}_{[44 \pm 1]}, I I_{[92 \pm 3]}$, Ttn, Usp ${ }_{[\sim 25]}, Q z$ & $148, \mathrm{C}$ \\
\hline $2000(10)$ & $800(10)$ & 281 & $\mathrm{Wo}_{50} \mathrm{FS}_{50}-\mathrm{II}_{100}$ & Ttn, Usp $\mathbf{U s}_{42 \pm 4}, \mathbf{Q z}, \mathrm{Hd}, \|$ & 135 \\
\hline $2000(10)$ & $800(10)$ & 281 & Ttn-2/3Mt-Qz & Ttn, Usp 20 to $38.35+5], Q z, H d$ & 136 \\
\hline $2000(10)$ & $690(10)$ & 720 & $\mathrm{Wo}_{45} \mathrm{Fs}_{55}-3 \mathrm{II}_{95}$ & 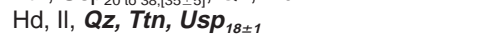 & $153, \mathrm{C}$ \\
\hline
\end{tabular}


TABLE 6-Continued

\begin{tabular}{|c|c|c|c|c|c|}
\hline$P$ (bar) & $T\left({ }^{\circ} \mathrm{C}\right)$ & $\begin{array}{l}\text { Duration } \\
\text { (h) }\end{array}$ & Reactants & Products & Experiment no. \\
\hline $2000(10)$ & $690(10)$ & 720 & Ttn-Usp $60-Q z$ & Ttn, Usp $\mathrm{s}_{27.5 \pm 2}, \mathrm{Qz}, / /$ & 154 \\
\hline $2000(10)$ & $656(10)$ & 360 & $\mathrm{Wo}_{45} \mathrm{Fs}_{55}-\mathrm{II}_{100}$ & Ttn, $\mathbf{Q z}, \boldsymbol{M t}_{s s} ?, \mathrm{Hd}, \|$ & 11 \\
\hline $2000(10)$ & $656(10)$ & 360 & $\mathrm{Ttn}-2 / 3 \mathrm{Mt}-\mathrm{Qz}$ & Ttn, Usp ${ }_{[16 \pm 4]}, \mathrm{Qz}, H d$ & 12 \\
\hline 1020(10) & $800(10)$ & 281 & $\mathrm{Wo}_{45} \mathrm{Fs}_{55}-3 \mathrm{II}_{100}$ & Ttn, Usp $\mathbf{p}_{44 \pm 3,[43 \pm 2]}, \mathbf{Q z}, \mathrm{Hd}, / /$ & $3, \mathrm{C}$ \\
\hline 1020(10) & $800(10)$ & 281 & $\operatorname{Ttn}-2 / 3 \mathrm{Mt}-\mathrm{Qz}$ & Ttn, Usp ${ }_{[43 \pm 4]}, \mathrm{Qz}, \mathrm{Hd}$ & 4 \\
\hline $1010(10)$ & $700(10)$ & 930.5 & $\mathrm{Wo}_{45} \mathrm{Fs}_{55}-3 \|_{100}$ & Ttn, Usp $_{[35 ?]}, \mathbf{Q z}, \mathrm{Hd}, \|_{[97 \pm 3]}$ & 17 \\
\hline $1010(10)$ & $700(10)$ & 930.5 & $\mathrm{Ttn}-2 / 3 \mathrm{Mt}-\mathrm{Qz}$ & Ttn, Usp ${ }_{[27 \pm 5]}, \mathrm{Qz}, \mathrm{Hd}$ & 18 \\
\hline
\end{tabular}

Note: Representation as in Table 5.

nary solution calorimetry experiments of titanite at 702 ${ }^{\circ} \mathrm{C}$ in $2 \mathrm{PbO} \cdot \mathrm{B}_{2} \mathrm{O}_{3}$ solvent ( $\mathrm{S}$. Fritsch, written communication). This value is $2 \mathrm{~kJ} / \mathrm{mol}$ greater than the one calculated with the existing heat capacity equations (Robie et al. 1978; Robie and Hemingway 1995; Berman 1988, 1991), which are based on the data of King et al. (1954). However, it compares well with the original data if the latter are corrected for $1 \%$ phase impurities (King et al. 1954), either $\mathrm{CaSiO}_{3}$ or $\mathrm{CaTiSiO}_{5}$ glass, or both (Xirouchakis et al. 1997b). The heat capacity equation parameters reported by Berman $(1988,1991)$ were used as starting points in the optimization. The $a_{3}, a_{6}$, and $a_{7}$ terms were set equal to zero, and $a_{2}$ and $a_{4}$ were constrained to be negative (Berman and Brown 1985). However, it was found best to fix the $a_{1}$ and $a_{2}$ terms at their given values $5.91460608 \times 10^{8}$ and $-5.118324 \times 10^{6}$, respectively (Berman 1988, 1991). The optimized heat capacity equation:

$C_{\mathrm{p}}=\frac{591460608}{T^{3}}-\frac{5118324}{T^{2}}-\frac{1038.4}{\sqrt{T}}+247.47$

results in positive deviations of $2 \%$ relative to the currently available experimental data at $\mathrm{T} \leq 500 \mathrm{~K}$ (King et al. 1954; Zhang et al. 1995) and $5 \%$ at $500 \leq T \leq 850$ $\mathrm{K}$ (Zhang et al. 1995). Consequently, the calculated heat content $\left(H_{\mathrm{T}}-H_{298}\right)$ deviates positively by $5 \%$ relative to the original high-temperature heat content data (King et al. 1954). Equation 14 may overestimate the heat capacity and heat content of titanite at high temperature. However, the positive deviations are consistent with corrections that account for contributions mainly from phase impurities (e.g., $\mathrm{CaTiSiO}_{5}$ glass, $\mathrm{CaSiO}_{3}$ ). Contributions from other types of defects (vacancies?) in the samples of King et al. (1954) and Zhang et al. (1995) are probable but cannot be accounted for as readily.

In a second set of calculations, the preferred set of parameters that describe the ilmenite and magnetite activities (Akimoto model) were allowed to vary within the reported range (Andersen and Lindsley 1988). Similarly, it was found best to optimize at least one of the heat capacity polynomial terms along with the rest of the parameters, i.e., $\Delta H^{0}, S^{0}$, and $W_{i j}$. The differences in the derived $\Delta H^{0}, S^{0}$, and heat capacity equation:

$C_{\mathrm{p}}=\frac{591460608}{T^{3}}-\frac{5118324}{T^{2}}-\frac{1040.1}{\sqrt{T}}+244.34$

are marginal despite the somewhat smaller positive deviations $(1-3 \%)$ relative to the currently available heat capacity and heat content when compared with Equation 14. The improvement in fitting the experimental data is also minimal. The enthalpy of formation and entropy for titanite consistent with the data in Andersen et al. (1993) are given in rows 1 (preferred) and 2 of Table 7. The graphical solution is shown in Figure 7. Subsequently, the positions of the Ttn-, $\mathrm{Fa}_{\mathrm{ss}}{ }^{-}$, and $\mathrm{Mt}_{\mathrm{ss}}$ and $\mathrm{Qz}$-absent reactions (Fig. 2) were determined (Fig. 3, 4, 5, and 6). The calculations were performed with the enthalpy and entropy values that are consistent with Equation 14 and the preferred $W_{\mathrm{ij}}$ values for ilmenite and magnetite (Andersen and Lindsley 1988), and by minimizing the absolute value (Grace 1990) of the Gibbs free energy,

TABLE 7. Thermodynamic data for titanite

\begin{tabular}{|c|c|c|c|c|}
\hline $\begin{array}{c}\Delta H_{1 \text { bar, } 298}^{0} \\
\mathrm{~kJ} / \mathrm{mol}\end{array}$ & $\begin{array}{l}S_{1 \text { bar, } 298}^{0} \\
\mathrm{~J} / \mathrm{mol} \cdot \mathrm{K}\end{array}$ & $\begin{array}{c}\Delta G_{1 \text { bar, } 298}^{0} \\
\mathrm{~kJ} / \mathrm{mol}\end{array}$ & $\begin{array}{c}V_{1 \text { bar, } 298}^{0} \\
\mathrm{~J} / \mathrm{bar}\end{array}$ & Source \\
\hline $\begin{array}{l}-2607.41 \\
-2607.20 \\
-2610.13 \pm 2.90 \\
-2596.60 \pm 3.00 \\
-2601.40 \pm 2.34 \\
-2596.27 \\
-2596.56 \\
-2596.48 \pm 1.77 \\
-2601.40 \pm 2.40\end{array}$ & $\begin{array}{l}106.00 \\
107.52 \\
\\
129.20 \pm 0.80 \\
129.20 \pm 0.84 \\
126.27 \\
129.29 \\
129.20 \\
129.20\end{array}$ & $\begin{array}{l}-2458.95 \\
-2459.20 \\
-2454.60 \pm 3.20 \\
-2459.86 \pm 2.43 \\
-2453.80 \\
-2454.20 \\
-2459.60 \\
-2459.86\end{array}$ & $\begin{array}{l}5.560 \pm 0.002 \\
5.560 \pm 0.002 \\
\\
5.574 \pm 0.007 \\
5.565 \\
5.565 \\
5.565 \\
5.565 \\
5.565\end{array}$ & $\begin{array}{l}1 \mathrm{a}, \text { preferred } \\
1 \mathrm{~b} \\
2 \\
3 \\
4 \\
5 \\
6 \\
7 \\
8\end{array}$ \\
\hline
\end{tabular}

Note: (1a) This study, consistent with Equation 14; (1b) This study, consistent with Equation 15; (2) Xirouchakis et al. 1997b; (3) Robie and Hemingway 1995; (4) Robie et al. 1978; (5) Xirouchakis and Lindsley 1995; (6) Berman 1988, 1991; (7) Holland and Powell $1990 ;(8)$ Holland and Powell 1985. 


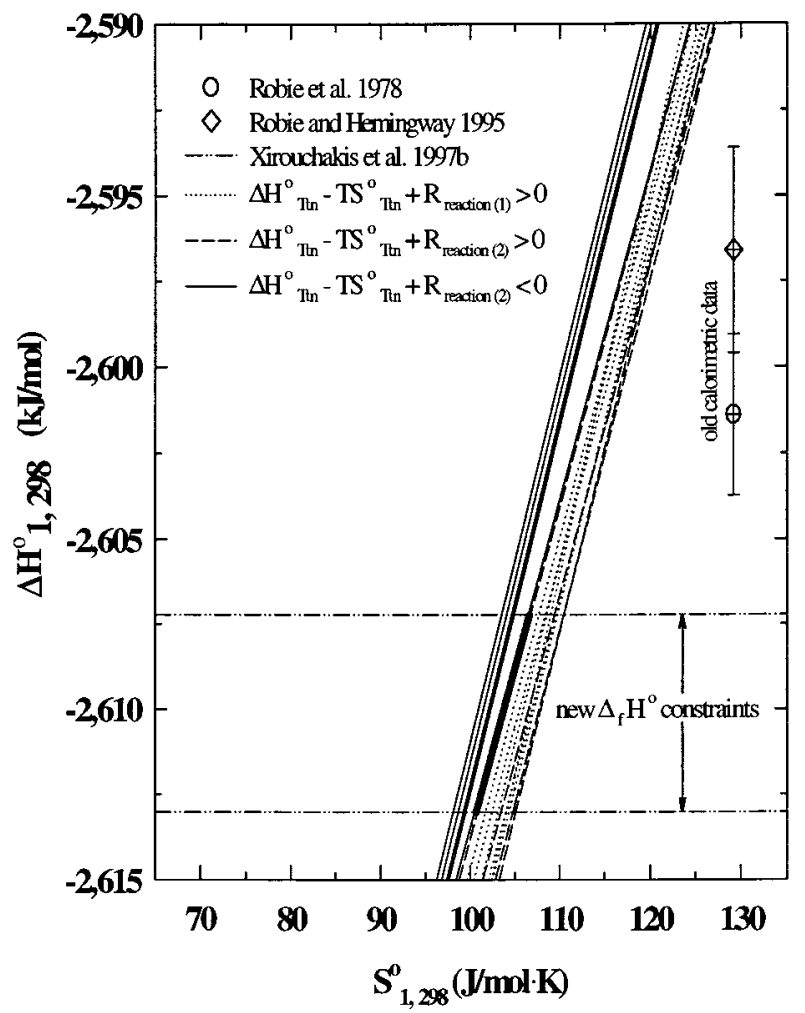

Figure 7. Feasible solution (filled area) for $\Delta H^{0}$ and $S^{0}$ of titanite as defined by calorimetry and phase equilibrium constraints from reactions 1 and 2. The latter were constructed using the midpoints for each experiment and average mineral compositions and the derived heat capacity polynomial for titanite. $R$ represents the contribution of all the input parameters but $\Delta H^{0}$ and $S^{0}$ in Equations 7 and 8.

$$
\left|\Delta G_{r}\right|=\left|\sum_{i}^{n} v_{i}^{j} \cdot \mu_{i}^{j}\right|=0,
$$

of the appropriate oxide and oxide-silicate equilibria (Table 1). We did not calculate the $\mathrm{Il}_{\mathrm{ss}}-$ and $\mathrm{Hd}_{\mathrm{ss}}$-absent reactions (Fig. 2) both because they are fairly well constrained by the rest of the equilibria and because of numerical problems at $T \leq 550{ }^{\circ} \mathrm{C}$. For reaction 1 we calculated the equilibrium conditions assuming $\mathrm{a}_{\mathrm{SiO}_{2}}=1$ with respect to quartz and solved for $f_{\mathrm{O}_{2}}$ at various pressure and temperature conditions. The agreement between experimental data and calculated phase relations is good except for reaction 2 at 1 bar and at $T>940{ }^{\circ} \mathrm{C}$ (Fig. 3). The dashed-dotted line represents the approximate location of the metastable extension of the isobarically univariant assemblage $\mathrm{Hd}_{\mathrm{ss}}+\mathrm{Il}_{\mathrm{ss}}+\mathrm{Ttn}+\mathrm{Mt}_{\mathrm{ss}}+$ cristobalite, especially in the range $940-960{ }^{\circ} \mathrm{C}$. The Haas database does not contain data for tridymite and no equation of state is presently available for pyroxenoid (ferrobustamite) solid solutions. End-member $\left(\mathrm{CaFeSi}_{2} \mathrm{O}_{6}\right)$ hedenbergite transforms directly to pyroxenoid (Pxd) of the same composition at $\geq 940{ }^{\circ} \mathrm{C}$. In the range $940-960{ }^{\circ} \mathrm{C}$ hedenbergite transforms to a Ca-rich hedenbergite ${ }_{\mathrm{ss}}$ and an Fe-rich pyrox- enoid ${ }_{\mathrm{ss}}\left(\operatorname{Pxd}_{\mathrm{ss}}\right)$, relative to the original composition of the low-temperature hedenbergite ${ }_{\mathrm{ss}}$. Finally, hedenbergite ss $_{\text {sans- }}$ forms to pyroxenoid ${ }_{\mathrm{ss}}$ of the same bulk composition at $\geq 960{ }^{\circ} \mathrm{C}$ (Lindsley and Munoz 1969). Calculations based on the phase relations established by Lindsley and Munoz (1969) in the range $940-960{ }^{\circ} \mathrm{C}$ and available thermochemical data (O'Neill and Navrotsky 1980; Haselton et al. 1987) for $\left(\mathrm{CaFeSi}_{2} \mathrm{O}_{6}\right)$ ferrobustamite, suggest that the assemblage (Fe-rich) $\mathrm{Pxd}_{\mathrm{ss}}+\left(\right.$ Ca-rich) $\mathrm{Hd}_{\mathrm{ss}}+\mathrm{Il}_{\mathrm{ss}}+\mathrm{Ttn}+\mathrm{Mt}_{\mathrm{ss}}$ + cristobalite should lie at lower $f_{\mathrm{O}_{2}}$ conditions than the assemblage $\mathrm{Hd}_{\mathrm{ss}}+\mathrm{Il}_{\mathrm{ss}}+\mathrm{Ttn}+\mathrm{Mt}_{\mathrm{ss}}+$ cristobalite. Consequently, the univariant assemblage $\mathrm{Pxd}_{\mathrm{ss}}+\mathrm{Il}_{\mathrm{ss}}+\mathrm{Ttn}+\mathrm{Mt}_{\mathrm{ss}}$ + cristobalite has to originate at lower $f_{\mathrm{O}_{2}}$ conditions than the approximately calculated $f_{\mathrm{O}_{2}}$ for the assemblage $\mathrm{Hd}_{\mathrm{ss}}+\mathrm{Il}_{\mathrm{ss}}+\mathrm{Ttn}+\mathrm{Mt}_{\mathrm{ss}}+$ cristobalite at $960{ }^{\circ} \mathrm{C}$. These estimates imply that the apparent disagreement is largely caused by the unaccounted effect of the hedenbergite $\mathrm{ss}_{\mathrm{ss}}$ to pyroxenoid $_{\mathrm{ss}}$ transformation at $\geq 940{ }^{\circ} \mathrm{C}$, and to a lesser extent by the quartz to tridymite transformation below $900{ }^{\circ} \mathrm{C}$, and partial melting at $\geq 1050 \pm 10^{\circ} \mathrm{C}$.

Our primary goal has been to incorporate titanite into the QUIIF database. The thermodynamic data for the rest of the phases in QUIlF (olivine, pyroxenes, Fe-Ti oxides, and quartz) have been optimized for a small, well-constrained experimental database (Davidson and Lindsley 1989; Andersen et al. 1991), and thus the inherent uncertainties are small. However, it is also useful to assess the impact of our new phase equilibrium and calorimetric data on other, more broadly based databases. In particular, it would be useful to know whether the need to revise the entropy and heat capacity for titanite depends only on our choice of the QUIIF thermodynamic database and solution models (Andersen et al. 1993).

Our new entropy values for titanite ( $A 2 / a$ space group) are specific to the QUIIF database and must not be exported directly to other databases, but we can assess whether those databases require revision. As already noted, neither the database of Berman (1991) nor that of Holland and Powell (1990) predicts the location of reaction 1 accurately, giving 1 bar values of $1000{ }^{\circ} \mathrm{C}$ and $-62{ }^{\circ} \mathrm{C}$, respectively. Clearly, then, data for at least one of the phases hedenbergite, ilmenite, titanite, and fayalite in each of those databases requires revision. However, identifying the problem phase(s) is not straightforward. Revision of data for titanite alone is unlikely to resolve the discrepancy. Both databases reproduce the experimental data of Jacobs and Kerrick (1981), but only the Berman database also predicts the data of Manning and Bohlen (1991). This strongly suggests that the values for titanite in both these databases are consistent with the phases in the Jacobs and Kerrick (1981) experiments (i.e., rutile, quartz, calcite, $\mathrm{CO}_{2}-\mathrm{H}_{2} \mathrm{O}-\mathrm{NaCl}$ mixtures). Therefore, the inability of both databases to predict reaction 1 , and of Holland and Powell (1990) to predict the Manning and Bohlen (1991) experiments, suggest inconsistencies among the values for titanite, fayalite, hedenbergite, ilmenite, anorthite, and kyanite in these databases.

In the following discussion we concentrate on reaction 


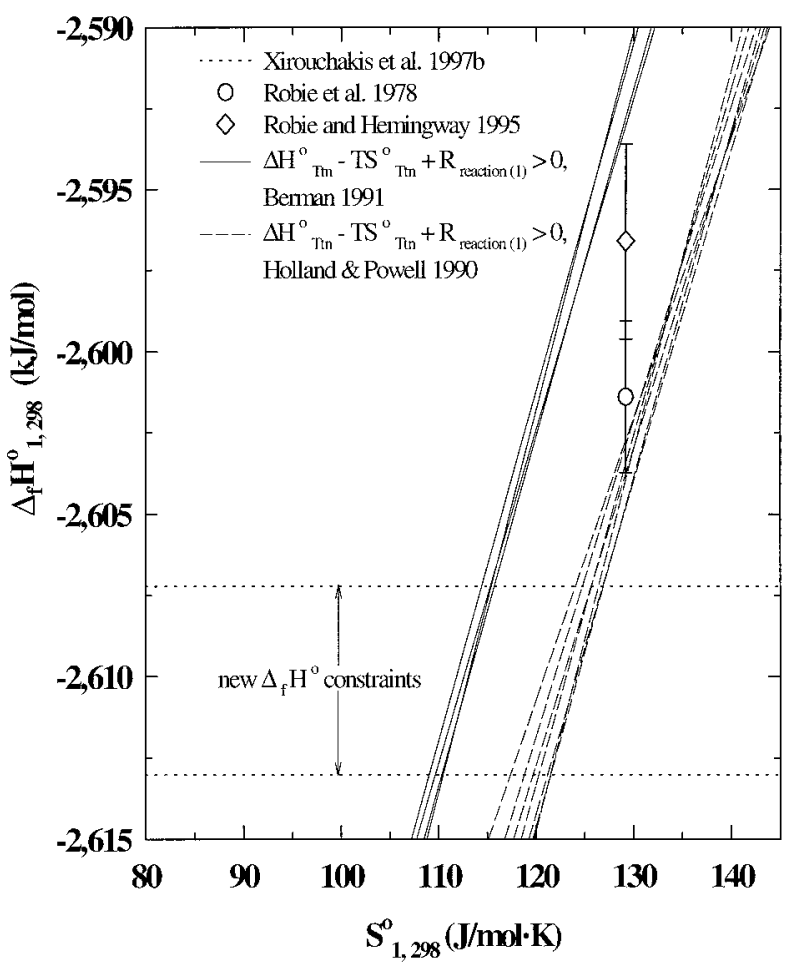

Figure 8. Feasible solution for $\Delta H^{0}$ and $S^{0}$ of titanite as defined by calorimetry and phase-equilibrium constraints based only on the reaction $\mathrm{Ttn}+\mathrm{Fa} \rightarrow \mathrm{Hd}_{\mathrm{ss}}+\mathrm{Il}_{\mathrm{ss}}$. The lines were constructed using the midpoints for each experiment, average mineral compositions, ideal site mixing for $\mathrm{Hd}_{\mathrm{ss}}$ and $\mathrm{Il}_{\mathrm{ss}}$ solid solutions, and thermodynamic data for all phases from the Berman (1991) (straight lines) and Holland and Powell (1990) (dashed lines). $R$ represents the contribution of all the input parameters but $\Delta H^{0}$ and $S^{0}$ in Equation 7.

1 because the phases involved are more nearly pure, and thus there is less need to invoke activity models than would be required for reaction 2 . We performed calculations using the experimental results for reaction 1 and the Berman (1991) and Holland and Powell (1990) thermodynamic databases. The activities of hedenbergite ${ }_{\mathrm{ss}}$ and ilmenite ${ }_{\mathrm{ss}}$ were approximated using ideal site mixing models. We used the heat capacities given by Berman (1991) and Holland and Powell (1990), and thermal expansivity and compressibility terms for titanite based on the data of Taylor and Brown (1976), Kunz et al. (1996), and Angel et al. (unpublished manuscript). The results of these calculations are shown graphically in Figure 8.

Regardless of the database used or the choice of heat capacity equation, the derived entropy values are smaller than the currently accepted entropy of $129.20 \pm 0.84 \mathrm{~J} /$ $(\mathrm{mol} \cdot \mathrm{K})$. Most importantly, the calculations suggest that the proposed change in entropy is largely independent of the thermodynamic database but it is required by the adopted enthalpy of formation (cf. Fig. 7 and 8). An enthalpy of formation for titanite of $-2610.13 \pm 2.90 \mathrm{~kJ} /$ mol (Xirouchakis et al. 1997b) is more consistent with entropy values either smaller than $110 \mathrm{~J} /(\mathrm{mol} \cdot \mathrm{K})$ (Berman
1991) or $120 \mathrm{~J} /(\mathrm{mol} \cdot \mathrm{K}$ ) (Holland and Powell 1990) (Fig. 8). In contrast, an entropy value at about $129.20 \mathrm{~J} /(\mathrm{mol} \cdot \mathrm{K})$ (King et al. 1954) appears to be consistent with the older enthalpy values either less negative than $-2597 \mathrm{~kJ} / \mathrm{mol}$ (Holland and Powell 1990; Berman 1991; Robie and Hemingway 1995; Xirouchakis and Lindsley 1995) or $-2602 \mathrm{~kJ} / \mathrm{mol}$ (Robie et al. 1978; Holland and Powell 1985) (Fig. 8). It would be presumptuous and highly inappropriate for us to recommend specific revisions to the databases of Berman (1991) and of Holland and Powell (1990). The values we have calculated for titanite and present graphically using those databases are for comparison only and must not be viewed as "corrections" to them. Clearly, new measurements on the heat capacity of titanite, using well-characterized material that is stoichiometric and pure, are urgently needed to test this conclusion.

This study clearly supports Wones (1989) argument that the assemblage hedenbergite ${ }_{\mathrm{ss}}$ - lmenite $_{\mathrm{ss}}$ indicates relatively reducing conditions compared to titanite-magnetite $_{\mathrm{ss}}$-quartz. However, our results demonstrate quantitatively that the stable equilibrium positions of reaction 1 and 2 reflect changes in pressure, temperature, $f_{\mathrm{O}_{2}}, \mathrm{a}_{\mathrm{Si}_{2}}$, $\mu \mathrm{Fe}^{2+} \mathrm{Ti}^{4+} \mathrm{Fe}_{-2}^{3+}$, and $\mu \mathrm{CaFe}_{-1}$. The differences in temperature and oxygen fugacity between the equilibrium position of the reactions as calculated for pure phases vs. solid solutions with our data can be significant in the range 650 to $1000{ }^{\circ} \mathrm{C}$ (i.e., $50-60{ }^{\circ} \mathrm{C}$ for reaction 1 , and 0.1 to $1 \log f_{\mathrm{O}_{2}}$ units for reaction 2). Furthermore, the stable assemblage $\mathrm{Ttn}-\mathrm{Mt}_{\mathrm{ss}}-\mathrm{Qz}$ is not necessarily indicative of oxygen fugacity conditions higher than that of the FMQ buffer. The experimental and calculated phase relations indicate that reaction 2 is not constrained to lie either below or above the FMQ buffer curve. We also estimate that at 1 bar, the stable invariant point I should lie at $612{ }^{\circ} \mathrm{C}$ and $-0.19 \log$ unit below FMQ (Fig. 2); in contrast, the metastable invariant point should lie at 675 ${ }^{\circ} \mathrm{C}$ and on the FMQ buffer. The stable invariant point I is displaced to lower temperatures with increasing pressure but also it remains below the FMQ buffer reaction curve (Fig. 2). Programs to calculate titanite-bearing oxide-silicate equilibria will be made available upon request to the second author.

\section{ACKNOWLEDGMENTS}

We thank R.G. Berman and E. Essene for constructive critisicism; P.M. Davidson, B.R. Frost, D.M. Jenkins, H. Nekvasil, J.B. Parise, R.J. Reeder, and G.H. Symmes for helpful comments and discussions; A.C. Simon for reading earlier versions of the manuscript. We bear, however, sole responsibility for the conclusions. This work was supported by NSF grants EAR9218329 and EAR-9304699 to Donald H. Lindsley. This is Stony Brook Mineral Physics Institute contribution 219.

\section{REFERENCES CITED}

Andersen, D.J. and Lindsley, D.H. (1988) Internally consistent solution models for Fe-Mg-Mn-Ti oxides: Fe-Ti oxides. American Mineralogist, 73, 714-726.

Andersen, D.J., Bishop, F.C., and Lindsley, D.H. (1991) Internally consistent solution models for Fe-Mg-Mn-Ti oxides: Fe-Mg-Ti oxides and olivine. American Mineralogist, 76, 427-444. 
Andersen, D.J., Lindsley, D.H., and Davidson, P.M. (1993) QUILF: A Pascal program to assess equilibria among Fe-Mg-Mn-Ti oxides, pyroxenes, olivine, and quartz. Computers and Geosciences, 19, 9, 13331350.

Berman, R.G. (1988) Internally-consistent thermodynamic data for minerals in the system $\mathrm{Na}_{2} \mathrm{O}-\mathrm{K}_{2} \mathrm{O}-\mathrm{CaO}-\mathrm{MgO}-\mathrm{FeO}-\mathrm{Fe}_{2} \mathrm{O}_{3}-\mathrm{Al}_{2} \mathrm{O}_{3}-\mathrm{SiO}_{2}-\mathrm{TiO}_{2}-$ $\mathrm{H}_{2} \mathrm{O}-\mathrm{CO}_{2}$. Journal of Petrology, 29, 445-522.

(1991) Thermobarometry using multi-equilibrium calculations: a new technique, with petrological applications. Canadian Mineralogist, 29, 833-855.

Berman, R.G. and Brown, T.H. (1985) Heat capacity of minerals in the system $\mathrm{Na}_{2} \mathrm{O}-\mathrm{K}_{2} \mathrm{O}-\mathrm{CaO}-\mathrm{MgO}-\mathrm{FeO}-\mathrm{Fe}_{2} \mathrm{O}_{3}-\mathrm{Al}_{2} \mathrm{O} 3-\mathrm{SiO}_{2}-\mathrm{TiO}_{2}-\mathrm{H}_{2} \mathrm{O}-\mathrm{CO}_{2}$ : representation, estimation, and high temperature extrapolation. Contributions to Mineralogy and Petrology, 89, 168-183.

Berman, R.G., Engi, M., Greenwood, H.J., and Brown, T.H. (1986) Derivation of internally-consistent thermodynamic data by the technique of mathematical programming, a review with application to the system $\mathrm{MgO}-\mathrm{SiO}_{2}-\mathrm{H}_{2} \mathrm{O}$. Journal of Petrology, 27, 1331-1364.

Clifford, A.A. (1973) Multivariate error analysis; a handbook of error propagation and calculation in many parameter systems, $112 \mathrm{p}$. Wiley, New York.

Day, H.W. and Kumin, H.J. (1980) Thermodynamic analysis of the aluminum silicate triple point. American Journal of Science, 280, 265287.

Davidson, P.M. and Lindsley, D.H. (1989) Thermodynamic analysis of pyroxene-olivine-quartz equilibria in the system $\mathrm{CaO}-\mathrm{MgO}-\mathrm{FeO}-\mathrm{SiO}_{2}$. American Mineralogist, 74, 18-30.

- (1994) Effect of Ca content and $\mathrm{SiO}_{2}$ activity on augite + olivine equilibria. American Mineralogist, 79, 1123-1124.

Deer, W.A., Howie, R.A., and Zussman, J. (1982) Rock-forming minerals, Orthosilicates, 1A, 443-466.

Franz, G. and Spear, F.S. (1985) Aluminous titanite (sphene) from the eclogite zone, south-central Taurern Window, Austria. Chemical Geology, 50, 33-46.

Frost, B.R. and Lindsley, D.H. (1992) Equilibria among Fe-Ti oxides, pyroxenes, olivine, and quartz: Part II. Application. American Mineralogist, 77, 1004-1020.

Frost, B.R., Lindsley, D.H., and Andersen, D.J. (1988) Fe-Ti oxide-silicate equilibria: Assemblages with fayalitic olivine. American Mineralogist, 73, 727-740.

Gascoyne, M. (1986) Evidence for the stability of the potential nuclear waste host, sphene, over geological time, from uranium-lead ages and uranium-series measurements. Applied Geochemistry, 1, 199-210.

Gieré, R. (1992) Compositional variation of metasomatic titanite from Adamello (Italy). Swiss Bulletin of Mineralogy and Petrology, 72, 167177.

Ghiorso, M.S. (1990) Thermodynamic properties of hematite-ilmenite-geikielite solid solutions. Contributions to Mineralogy and Petrology, 104, 645-667.

Ghiorso, M.S. and Sack, R.O. (1991) Fe-Ti oxide geothermometry: thermodynamic formulation and the estimation of intensive variables in silicic magmas. Contributions to Mineralogy and Petrology, 108, 485510.

Ghose, S., Ito, Y., and Hatch, D.M. (1991) Paraelectric-antiferroelectric phase transition in titanite $\mathrm{CaTiSiO}_{5}$ : I. A high temperature x-ray diffraction study of the order parameter and transition mechanism. Physics and Chemistry of Minerals, 17, 591-603.

Gordon, T.M. (1973) Determination of internally consistent thermodynamic data from phase equilibrium experiments. Journal of Geology, 81, 199-208.

Grace, A. (1990) Optimization toolbox for use with MATLAB 75 p. The MathWorks Inc. Natick, Massachusetts.

Haas, J.L. and Fisher, J.R. (1976) Simultaneous evaluation and correlation of thermodynamic data. American Journal of Science, 276, 249-256.

Haas, J.L. and Hemingway, B.S. (1992) Recommended standard electrochemical potentials and fugacities of oxygen for solid buffers and thermodynamic data in the systems iron-silicon-oxygen, nickel-oxygen, and copper-oxygen. U.S. Geological Survey Open-File Report 92-267.

Haselton, H.T. Jr., Robie, R.A., and Hemingway, B.S. (1987) Heat capac- ities of synthetic hedenbergite, ferrobustamite, and $\mathrm{CaFeSi}_{2} \mathrm{O}_{6}$ glass. Geochimica et Cosmochimica Acta, 51, 2211-2217.

Hayward, P. and Cechetto, E. (1982) Development of sphene-based glass ceramics tailored for Canadian waste disposal conditions. In S. Topp, Ed., Scientific basis for nuclear management, 3, 91-98. Elsevier, Boston.

Holland, T.J.B. and Powell, R. (1985) An internally consistent thermodynamic data set with uncertainties and correlations: the system $\mathrm{Na}_{2} \mathrm{O}$ $\mathrm{K}_{2} \mathrm{O}-\mathrm{CaO}-\mathrm{MgO}-\mathrm{FeO}-\mathrm{Fe}_{2} \mathrm{O}_{3}-\mathrm{Al}_{2} \mathrm{O}_{3}-\mathrm{SiO}_{2}-\mathrm{TiO}_{2}-\mathrm{C}-\mathrm{H}_{2}-\mathrm{O}_{2}$. Journal of Metamorphic Geology, 3, 343-370.

(1990) An enlarged and updated internally consistent thermodynamic data set with uncertainties and correlations: the system $\mathrm{Na}_{2} \mathrm{O}$ $\mathrm{K}_{2} \mathrm{O}-\mathrm{CaO}-\mathrm{MgO}-\mathrm{FeO}-\mathrm{Fe}_{2} \mathrm{O}_{3}-\mathrm{Al}_{2} \mathrm{O} 3-\mathrm{SiO}_{2}-\mathrm{TiO}_{2}-\mathrm{C}-\mathrm{H}_{2}-\mathrm{O}_{2}$. Journal of Metamorphic Geology, 8, 89-124.

Hughes, J.M., Bloodaxe, E.S., Hanchar, J.M., and Foord, E.E. (1997) Incorporation of rare earth elements in titanite: Stabilization of the $A 2 / a$ dimorph by creation of antiphase boundaries. American Mineralogist, $82,512-516$

Hunt, J.A. and Kerrick, D.M. (1977) The stability of sphene: experimental redetermination and geologic implications. Geochimica et Cosmochimica Acta, 41, 279-288.

Jacobs, G.K. and Kerrick, D.M. (1981) Devolatilization equilibria in $\mathrm{H}_{2} \mathrm{O}$ $\mathrm{CO}_{2}$ and $\mathrm{H}_{2} \mathrm{O}-\mathrm{CO}_{2}-\mathrm{NaCl}$ fluids: an experimental and thermodynamic evaluation at elevated pressures and temperatures. American Mineralogist, 66, 1135-1153.

Kerrick, D.M. (1987) Cold-Seal Systems. In G.C. Ulmer and H.L. Barnes, Eds., Hydrothermal experimental techniques, 523 p. Wiley, New York.

King, E.G., Orr, R.L., and Bonnickson, K.R. (1954) Low temperature heat capacity, entropy at $298.16 \mathrm{~K}$, and high temperature heat content of Sphene $\left(\mathrm{CaTiSiO}_{5}\right)$. American Chemical Society Journal, 76, 43204321.

Kunz, M., Xirouchakis, D., Häuserman, D., and Lindsley, D.H. (1996) High-pressure transition in titanite $\left(\mathrm{CaTiOSiO}_{4}\right)$. American Mineralogist, $81,1527-1530$.

Lindsley, D.H. and Frost, R.B. (1992) Equilibria among Fe-Ti oxides, pyroxenes, olivine, and quartz: Part I. Theory. American Mineralogist, 77, 987-1003.

Lindsley, D.H. and Munoz, J.L. (1969) Subsolidus relations along the join hedenbergite-ferrosilite. American Journal of Science, Schairer volume, 267-A, 295-324.

Manning, C.E. and Bohlen, S.R. (1991) The reaction titanite + kyanite = anorthite + rutile and titanite-rutile barometry in eclogites. Contributions to Mineralogy and Petrology, 109, 1-9.

Nakada, S. (1991) Magmatic processes in titanite-bearing dacites, central Andes of Chile and Bolivia. American Mineralogist, 76, 548-560.

O'Neill, H.S.C. and Navrotsky, A. (1980) The thermodynamics of the clinopyroxene to pyroxenoid phase transition in the systems $\mathrm{CaO}$ "FeO" $-\mathrm{SiO}_{2}$ and $\mathrm{CaO}-\mathrm{MnO}-\mathrm{SiO}_{2}$. Eos 61, 1147.

Olbricht, W., Chatterjee, N.D., and Miller, K. (1994) Bayes estimation: a novel approach to derivation of internally consistent thermodynamic data for minerals, their uncertainties, and correlations. Part I. Theory. Physics and Chemistry of Minerals, 21, 36-49.

Robie, R.A. and Hemingway, B.S. (1995) Thermodynamic properties of minerals and related substances at $298.15 \mathrm{~K}$ and 1 bar $\left(10^{5}\right.$ Pascals $)$ pressure and at higher temperatures. Geological Survey Bulletin 2131.

Robie, R.A., Hemingway, B.S., and Fisher, J.R. (1978) Thermodynamic properties of minerals and related substances at $298.15 \mathrm{~K}$ and $1 \mathrm{Bar}$ $\left(10^{5}\right.$ Pascals $)$ pressure and at higher temperatures. Geological Survey Bulletin 1452

Robinson, G.R. Jr., Haas, J.L. Jr., Schafer, C.M., and Haselton, H.T. (1982) Thermodynamic and thermophysical properties of selected phases in the $\mathrm{MgO}-\mathrm{SiO}_{2}-\mathrm{H}_{2} \mathrm{O}-\mathrm{CO}_{2}, \mathrm{CaO}-\mathrm{Al}_{2} \mathrm{O}_{3}-\mathrm{SiO}_{2}-\mathrm{H}_{2} \mathrm{O}-\mathrm{CO}_{2}, \mathrm{Fe}-\mathrm{FeO}-\mathrm{Fe}_{2} \mathrm{O}_{3}-\mathrm{SiO}_{2}$ chemical systems with special emphasis on the properties of basalts and their mineral components. U.S. Geological Survey Open-file Report 8379, 429 p.

Sack, R.O. and Ghiorso, M.S. (1989) Importance of consideration of mixing properties in establishing an internally consistent thermodynamic database: thermochemistry of minerals in the system $\mathrm{Mg}_{2} \mathrm{SiO}_{4}-\mathrm{Fe}_{2} \mathrm{Si}_{2} \mathrm{O}_{4}$ $\mathrm{SiO}_{2}$. Contributions to Mineralogy and Petrology, 102, 1, 41-68.

(1994a) Thermodynamics of multicomponent pyroxenes: I. for- 
mation of a general model. Contribution to Mineralogy and Petrology, $116,277-286$

(1994b) Thermodynamics of multicomponent pyroxenes: II. phase relations in the quadrilateral. Contributions to Mineralogy and Petrology, 116, 287-300.

Spear, F.S. (1981) An experimental study of hornblende stability and compositional variability in amphibolite. American Journal of Science, 281, 697-734.

Tanaka, I., Obuchi, T., and Kojima, H. (1988) Growth and characterization of titanite $\left(\mathrm{CaTiSiO}_{5}\right)$ single crystals by the floating zone method. Journal of Crystal Growth, 87, 169-174.

Taylor, J.R. (1982) An introduction to error analysis: the study of uncertainties in physical measurements, 270 p., University Science Books, Mill Valley, California.

Todd, S.S. and Kelley, K.K. (1956) Heat and free-energy data for tricalcium dititanate, sphene, lithium metatitanate, and zinc-titanium spinel. U.S. Bureau of Mines Report of Investigations 5193.

Turnock, A.C., Lindsley, D.H., and Grover, J.E. (1973) Synthesis and unit cell parameters of $\mathrm{Ca}-\mathrm{Mg}-\mathrm{Fe}$ pyroxenes. American Mineralogist, 58, $50-59$

Wechler, B.A. and Prewitt, C.T. (1984) Crystal structure of ilmenite $\left(\mathrm{FeTiO}_{3}\right)$ at high temperature and at high pressure. American Mineralogist, 69, 176-185.
Wones, D. (1989) Significance of the assemblage titanite + magnetite + quartz in granitic rocks. American Mineralogist, 74, 744-749.

Xirouchakis, D. (1997) The stability and petrologic importance of titanite (sphene), 159 p. Ph. D. dissertation. State University of New York at Stony Brook.

Xirouchakis, D. and Lindsley, D.H. (1995) Low pressure equilibria among titanite (sphene), hedenbergite, iron-titanium oxides, and silica: experiments and internally consistent thermodynamic data for titanite. V.M. Goldschmidt Conference, Penn State, Program and Abstracts, 98.

Xirouchakis, D., Kunz, M., Parise, J.B., and Lindsley, D.H. (1997a) Synthesis methods and unit-cell volume of end-member titanite (CaTi$\mathrm{OSiO}_{4}$ ). American Mineralogist, 82, 748-753.

Xirouchakis, D., Fritsch, S., Putnam, L.R., Navrotsky, A., and Lindsley, D.H. (1997b) Thermochemistry and the enthalpy of formation of Synthetic end-member $\left(\mathrm{CaTiSiO}_{5}\right)$ titanite. American Mineralogist, 82, 754-759.

Zhang, M., Salje, E.K.H., Bismayer, U., Unruh, H.-G., Wruck, B., and Schimdt, C. (1995) Phase transition(s) in titanite $\mathrm{CaTiSiO}_{5}$ : an infrared spectroscopic, dielectric response and heat capacity study. Physics and Chemistry of Minerals, 22, 41-49.

ManusCRIPT RECEIVED May 23, 1997

MANusCript aCCePted February 10, 1998

PAPER handled By DAVID M. Jenkins 